\title{
Are audit fees discounted in initial year audit engagements? *
}

\author{
Abhijit Barua \\ School of Accounting \\ Florida International University \\ baruaa@fiu.edu \\ Clive Lennox \\ Leventhal School of Accounting \\ University of Southern California \\ clennox@usc.edu \\ Aneesh Raghunandan \\ Department of Accounting \\ London School of Economics \\ a.raghunandan@1se.ac.uk
}

November 2019

\begin{abstract}
Many studies report that audit fees are discounted in the year of an auditor change and regulators have long been concerned that such fee discounting could impair audit quality. We find significant bias in the way studies have tested for fee discounting. The bias exists because interim procedures are usually performed by both the predecessor and successor auditors but only the successor's fee needs to be disclosed. Accordingly, the disclosed fee during the auditor change year usually relates to a partial year of auditing services. We find that the evidence for fee discounting disappears after correcting for this measurement bias.
\end{abstract}

\footnotetext{
${ }^{*}$ We thank the editor (Michelle Hanlon) and Mark DeFond, Michael Ettredge, Ferdinand Gul, Jonathan Milian, K. Raghunandan, K. R. Subramanyam, Srinivasan Sankaraguruswamy, Scott Whisenant, Mike Wilkins, and workshop participants at the University of Kansas and Florida International University for useful comments on earlier versions of this paper. We also thank Safayat Hossain for his research assistance.
} 


\section{Introduction}

Legislators and regulators have long expressed concerns that audit quality can suffer when auditors offer abnormally low audit fees in order to attract new clients (U.S. Senate 1977; U.S. House of Representatives 1985; Treadway Commission [NCFFR] 1987; SEC 2000). Their concern is that a newly appointed auditor might be tempted to cut back on necessary audit procedures if the low audit fee is insufficient to cover the costs of conducting a competent audit. Moreover, the new auditor might compromise her independence to retain the client in subsequent years in order to recoup the losses that were previously incurred during the auditor change year. The concerns of regulators have been amplified by findings from the academic literature which appear to show that audit fees are significantly discounted during initial year audit engagements.

The literature on initial year fee discounting goes back almost forty years to a theoretical model by DeAngelo (1981), which assumes a perfectly competitive audit market in which it is costly for a company to switch to a new auditor. After winning a new engagement, auditors earn profits from their clients because the costs of changing auditor deter companies from switching to lower-priced auditors. Given perfect competition, the prospect of earning this stream of future profits induces auditors to offer cut-priced audits in the initial audit engagement. Thus, initial year fee discounting occurs as a result of competition. Chan (1999) extends the DeAngelo (1981) model by relaxing the assumption that auditors are homogeneous and competition is perfect. He shows that initial year fee discounting does not necessarily occur when audit firms compete on specialization as well as price because competition is less fierce in differentiated product markets where highly specialized auditors exercise market power.

One of the most robust findings from the empirical auditing literature is that audit fees are significantly discounted during the auditor change year (see Hay et al. (2006) for a review of the 
literature). In this paper, we argue that the empirical evidence is problematic due to a bias in the way that researchers measure audit fees during the auditor change year. The bias arises because successor auditors typically work for part of a year rather than a full year. This causes the successor's audit fee to be systematically biased downwards during the auditor change year. Although the year-end audit is by the successor auditor, the annual audit fee includes the amounts paid for quarterly reviews of interim financial statements; one or more of these interim reviews are usually performed by the predecessor auditor during the auditor change year. Moreover, companies are required to disclose the fee paid to the successor auditor but they are not required to disclose the fee paid to the predecessor. Accordingly, the disclosed audit fee during the auditor change year is usually for a partial year rather than a full year of services. This causes the disclosed audit fee to be biased downwards in initial year audit engagements.

We assess the recent evidence on fee discounting in initial year audits by surveying 34 studies published between 2011 and 2018. Of the 34 studies, we find that 27 report statistically significant fee discounting during the auditor change year. To obtain further information on how the studies arrived at their results, we contacted the authors to find out whether their audit fee variable captures the fee paid to the successor auditor, or the fee paid to the predecessor auditor (where this is disclosed), or the combined fee paid to the predecessor and successor auditors. ${ }^{1} \mathrm{We}$ received usable responses from the authors of 31 studies. The responses indicate that 27 studies use either the fee paid to the successor or the fee paid to the predecessor, whereas four studies use the combined fees of the successor and predecessor auditors where this information is available. Interestingly, the responses indicate that the researcher's approach to measuring audit fees during the auditor change year seems to account for the variation across studies in the estimated strength

\footnotetext{
${ }^{1}$ It was necessary for us to contact the authors because none of the 34 studies disclose this information in the published articles.
} 
of initial year fee discounting. In particular, the evidence for fee discounting is much stronger when researchers use only the fee paid to the successor or predecessor auditor, rather than their combined fees.

We conduct our own empirical analyses to further investigate these measurement issues. Our sample comprises 46,970 company-year observations from 2004 to 2015 and includes 3,102 initial year audit engagements. We find that most auditor change companies $(62 \%)$ disclose the fee paid to the successor auditor but do not disclose the fee paid to the predecessor auditor. Only $38 \%$ of the auditor change companies disclose both fee variables even though most successor auditors are appointed in the latter half of the fiscal year or subsequent to the year-end. These descriptive statistics suggest that the measurement bias arising from partial-year services is likely to be serious.

Next, we estimate audit fee models using the alternative approaches employed in prior literature. Following the approach of most studies, we first estimate models in which audit fees are measured using either the fee paid to the successor auditor or the fee paid to the predecessor auditor (but not both fees combined). Consistent with prior findings, the results appear to suggest highly significant fee discounting during the auditor change year. Next, we follow the approach of studies which use the combined fees paid to the successor and predecessor auditors (where the latter are disclosed). Specifically, the audit fee variable during the auditor change year equals the combined fees of the successor and predecessor auditors when companies disclose both, whereas the fee variable equals the fee paid to the successor auditor when companies do not disclose the predecessor's fee. We find that this approach yields much weaker evidence of fee discounting. Overall, these findings suggest that the measurement biases attributable to partial-year audits are most acute when researchers use either the successor's audit fee or the predecessor's audit fee, but 
not the two fees combined. Nevertheless, there are still significant biases when studies adopt the latter approach because most companies only disclose the fee paid to the successor auditor (not the fee paid to the predecessor), which makes it impossible to calculate their combined fees.

Next, we investigate whether the evidence continues to support initial year fee discounting when we take steps to address the measurement bias. First, we restrict the sample of auditor change companies to those that disclose the fee paid to the predecessor auditor as well as the successor auditor (i.e., we drop auditor change companies that disclose only the fee paid to the successor auditor). Using this approach, we find that audit fees are significantly larger during the auditor change year. This finding makes intuitive sense because some of the audit procedures performed by the predecessor auditor in the months before the auditor change would need to be repeated by the successor auditor when conducting the year-end audit.

A limitation of the first approach is that we restrict the sample to companies that voluntarily disclose the fees paid to successor and predecessor auditors, which could raise potential concerns about self-selection bias. In addition, the literature on initial year fee discounting is primarily concerned with the pricing strategy of the successor auditor rather than the predecessor. We address both concerns by examining the fee paid to the successor auditor during the first full year of services (i.e., the year following the auditor change). For example, if the successor auditor is appointed in November 20x4 to audit the financial statements for 31 December 20x4, the first fullyear would be 20x5. Using this approach, we find no evidence of fee discounting during the first full-year audit following an auditor change.

A limitation of the second approach is that the literature on initial year fee discounting is primarily concerned with the successor auditor's pricing strategy during the year of the auditor change. To address this concern, we identify the date that the successor auditor is appointed in 
order to estimate the downward bias that arises from partial-year audits. We expect the bias is smaller when the successor auditor is appointed earlier in the year and, in extremis, the bias completely disappears if the successor auditor is appointed at the very beginning of the fiscal year. Accordingly, we include an indicator variable (INITIAL) which takes the value one for initial year audits (zero otherwise) and an interaction variable (INITIAL $\times$ LDAYS), where LDAYS equals the $\log$ of the number of days from the start of the fiscal year until the appointment of the successor auditor. In this specification, the INITIAL coefficient captures any fee discounting by the successor auditor in the presence of a full-year audit; i.e., where LDAYS $=0$. The coefficient on INITIAL is significantly positive suggesting that the successor's full-year audit fee is significantly higher in initial year audits. The coefficient on the interaction term $($ INITIAL $\times$ LDAYS) is negative and highly significant, which suggests that the downward bias in the successor's audit fee is greater when there is a longer delay between the beginning of the fiscal year and the date that the successor auditor is appointed.

Next, we add back the estimated downward bias (calculated using the INITIAL $\times$ LDAYS interaction variable) to estimate what the audit fee would have been if the successor auditor had been appointed at the very beginning of the fiscal year (i.e., where $L D A Y S=0$ ). We call this the successor auditor's corrected full-year fee. We then test whether this corrected full-year fee is abnormally low or abnormally high during the auditor change year. In this regression, we continue to find that the coefficient on INITIAL is positive and highly significant, suggesting that the fullyear fee is significantly higher during the auditor change year. Overall, our results suggest that the average company pays higher rather than lower audit fees during the auditor change year, which is opposite to the conclusions that have been reached in prior literature. 
That said, it is possible that fees are discounted for a minority of auditor change companies but these discounts are offset by higher audit fees at other auditor change companies. We use our estimate of the successor auditor's corrected full-year audit fee to examine whether such fee discounting is associated with low audit quality. Using several measures for audit quality (restatements, going-concern opinions, adverse internal control opinions, and abnormal accruals), we find no evidence that fee discounting in initial year audits is linked to impaired audit quality.

Our study contributes to the auditing literature by showing that the fee discounts documented in prior research are an artifact of partial-year audits rather than a differential pricing strategy by the successor auditor. This contradicts a commonly-held view that successor auditors offer lower audit fees during the auditor change year in order to attract new clients. Our findings have important implications for the audit fee literature because future research needs to account for successor auditors providing partial-year, rather than full-year, audit services. We suggest two ways in which researchers can address this issue. For researchers who are not interested in initial year audit fees, the simplest approach would be to drop auditor change observations from the sample given the significant measurement error in disclosed fees. For researchers who are interested in initial year audit fees, an alternative approach would be to control for the downward bias in the successor's audit fee during the auditor change year by adding a variable that explicitly controls for the timing of the successor auditor's appointment (the INITIAL $\times$ LDAYS interaction variable)

Our study has potential implications for the SEC, which has previously raised concerns about fee discounting in initial year audits (SEC 2000). Our study shows that these concerns are attributable to a disclosure anomaly, which arises because the SEC does not require companies to disclose the fees paid to predecessor auditors in an auditor change year. This disclosure anomaly 
has led to a misinterpretation of the fee data, with regulators and researchers attributing the lower levels of disclosed fees to a price discounting strategy whereas in fact the lower fees are attributable to a disclosure anomaly involving partial-year audits. We suggest that regulators consider whether companies should be required to disclose the fees paid to predecessor auditors as well as successor auditors in order to rectify this anomaly. Our study also has practical implications for regulators in countries where companies are not required to disclose the date that the successor auditor is appointed. Without information on the appointment date, it is much more difficult for financial statement users, researchers, and regulators to assess whether the successor's audit fee during the auditor change year is abnormally high or low.

Finally, given the concerns raised by regulators, it is perhaps surprising that there is very little evidence on the relation between initial year fee discounting and audit quality. One study by Gul et al. (2009) finds an insignificant association between audit fee discounting and clients' discretionary accruals. ${ }^{2}$ Our study contributes to the literature by using a corrected measure of the successor's full-year audit fee and by using multiple proxies for audit quality. We find no evidence of a link between fee discounting in initial year audits and low audit quality. Overall, our results suggest that regulatory concerns about fee discounting in initial year audits may be misplaced.

\section{Background}

\subsection{Legislative and Regulatory Concerns}

Legislators and regulators have periodically expressed concerns that audit quality could be impaired by initial year fee discounting (U.S. Senate 1977, 2002; AICPA 1978; U.S. House of

\footnotetext{
${ }^{2}$ Using data from China, Huang et al. (2015) find that sanctions for problem audits and greater earnings management are more likely with initial year fee discounting although they this result only holds when the change in audit firm is accompanied by a change in the signing partners.
} 
Representatives 1985; SEC 2000; Turner 2002a, 2002b). The SEC has asserted that fee discounting can create "a variety of independence issues" especially if audits are used as "loss leaders to be made up for with more lucrative consulting contracts" (SEC 2000). ${ }^{3}$ Similar concerns have been raised by regulators in other countries as well. For example, the Chinese Ministry of Finance promulgated rules in 2010 aimed at preventing initial year fee discounting (Huang et al. 2015). The European Commission's (2011) Green Paper on audit market issues has similarly claimed that initial year fee discounting is a concern, and it has suggested possible ways to address the practice, such as restricting non-audit services and requiring fixed period auditor appointments (i.e., mandatory audit firm rotation).

The main reason legislators and regulators are concerned about initial year fee discounting is their belief that auditors would want to recoup the losses incurred during the auditor change year by earning rents from a continuation of the audit engagement in future years. This, it is argued, can threaten auditor independence because it creates incentives for successor auditors to ensure that the relationship with the client continues into the future. Hence, successor auditors may be more lenient when negotiating with clients on matters relating to accounting judgments and audit adjustments in order to retain the client. ${ }^{4}$ Although this is a central concern of regulators, it is worth noting that their argument is not grounded in rational economic behavior. An auditor's foregone revenues in a previous year should not affect the auditor's behavior in subsequent years because

\footnotetext{
${ }^{3}$ The SEC (2000) further asserts that "Low-balling also sends a message to the auditor that the audit relationship is not as valuable as the consulting relationship. ... Low-balling sends a message inside the audit firm as well. ... The factors that drive a high quality audit, including the core values of the auditing profession, may diminish in importance to the firm, as will the influence of those firm members who exemplified those core values in their own professional careers."

${ }^{4}$ A former SEC chief accountant has asserted in congressional testimony that "auditors propose a lower fee in the first year of an audit relationship in order to gain the account, and this has a negative impact on the quality of the first year audit" (Turner 2002a).
} 
sunk costs should be irrelevant to future decisions if auditors are behaving as rational economic agents.

2.2 Interim services and audit fee disclosures during the auditor change year

In December 1999, the SEC adopted a rule requiring registrants to "obtain reviews of interim financial information by their independent auditors starting with their Forms 10-Q or 10-QSB to be filed for fiscal quarters ending on or after March 15, 2000." Normally, the predecessor auditor would perform the required reviews for one or more quarters because, in practice, most auditor changes occur well after the end of the first quarter. (Only 17\% of the 3,102 auditor changes in our sample occur during the first fiscal quarter.) Therefore, in most auditor change years, there is at least one interim review performed by the predecessor auditor.

If there is no change of auditor during the year, the fees for review services are included as part of the annual audit fee. In Financial Reporting Release No. 56, the SEC (2000) requires registrants to "aggregate and disclose the fee paid for the annual audit and for the review of the company's financial statements included in the company's Forms 10-Q or 10-QSB for the most recent fiscal year ... under a caption entitled 'Audit Fees"' (emphasis added). After the fee disclosure rule was issued, registrants had many questions and the SEC responded by issuing a list of "Frequently Asked Questions" (FAQ) in January 2001 (SEC 2001). In this FAQ, the SEC reiterated that any fees paid for reviews of quarterly filings should be included as part of the annual audit fee.

Critically, the SEC also issued clarification about how audit fees should be disclosed during an auditor change year. Specifically, question \#14 of the FAQ was as follows: "When there has been a change in accountants during the year, should fees paid to both the predecessor and 
successor auditor be disclosed pursuant to Item 9(e) of Schedule 14A?” The answer provided by the Office of the Chief Accountant was unequivocal: "No. The fee disclosure should only be made for the accountant who renders an audit opinion on the most recent year's financial statements." Therefore, companies are only required to disclose the fees paid to successor auditors. They are not required to disclose the fees paid to predecessor auditors, although they are free to do so on a voluntary basis if they so wish.

In January 2003, the SEC revised the fee disclosure rules by changing the categories of fees to be disclosed. Specifically, the SEC added two new categories (Audit Related Fees and Tax Fees) and eliminated one category (Financial Information Systems Design and Implementation Fees). However, the SEC's definition of audit fees continues to include fees for quarterly reviews, as well as any interim audit procedures and services related to comfort letters and other attestation services. These services can be performed at any time during the year. Therefore, if an auditor change happens at any time other than the beginning of the fiscal year it is likely that the predecessor auditor would perform some of the work and receive a fee for services rendered prior to the auditor change date. ${ }^{5}$

Although the fees paid to predecessor auditors do not have to be disclosed, in practice, some companies do voluntarily disclose them. In our sample, 38 percent of auditor change companies voluntarily disclose the fees paid to predecessor auditors. Moreover, the fee paid to the predecessor auditor can be substantial, which reflects that the predecessor auditor is often removed late in the fiscal year or after the fiscal year-end.

\subsection{The audit fees of predecessor and successor auditors in initial year audits}

\footnotetext{
${ }^{5}$ In a subsequent FAQ, the SEC reiterated that companies are not required to disclose fees paid to the predecessor auditor during the auditor change year (SEC 2007).
} 
In order to understand how the disclosure requirements are likely to affect audit fees, it is important to consider the timing of audit procedures by the predecessor and successor auditors. In an annual audit, a disproportionate amount of audit evidence is collected after the fiscal year-end. This is particularly true of balance sheet accounts - such as inventory, receivables, and cash - because evidential matter for the closing amounts of these balances is more reliable when the evidence is collected shortly after the year-end. ${ }^{6}$ It is also true of certain note disclosures - such as post-balance sheet date events - because these pertain to events that occur between the fiscal year-end date and the audit report date, which means that auditors need to collect the most up-to-date evidence prior to issuing the audit report.

The period after the fiscal year-end tends to be a very busy time for auditors because many clients share the same fiscal year-end date. In practice, the busy season usually stretches from December $31^{\text {st }}$ to early April, which is when much of the audit evidence is collected and most audit reports are issued. To mitigate the effects of the busy season, audit firms take steps to shift some of the audit work to the period before the fiscal year-end. This is feasible because certain audit procedures can be conducted during the year rather than after the fiscal year-end. For example, tests of internal controls can be undertaken throughout the fiscal year. ${ }^{7}$ Similarly, tests of income statement transactions can be undertaken throughout the fiscal year. ${ }^{8}$ Even balance sheet accounts can be tested before the fiscal year-end through the use of 'roll-forward' procedures. ${ }^{9}$ Thus, an

\footnotetext{
${ }^{6}$ For example, auditors usually attend physical inventory counts, send confirmation letters to test receivable balances, and send bank confirmations to confirm cash and loan accounts shortly after the year-end date.

${ }^{7}$ For example, if there is a change of accounting controller in June and the company's fiscal year-end is December, the auditor may spend part of the summer testing the effectiveness of internal controls in the period prior to the controller's departure. This is important so that the auditor can later assess whether the change in controller is associated with a change in the strength of internal controls.

${ }^{8}$ For example, if the company reports an abnormally large sale transaction in June and the company's fiscal year-end is December, the auditor may spend part of the summer testing whether the recorded sale transaction is valid.

${ }^{9}$ For example, an auditor may attend a physical inventory count six months before the fiscal year-end (June $30^{\text {th }}$ ) and, later, the auditor accounts for all inventory flows in the six-month period from July to December in order to audit the closing balance of inventory on December $31^{\text {st }}$. The latter are known as 'roll-forward' procedures.
} 
auditor can reduce the amount of work that is conducted during the busy season by shifting some of the work to the period before the fiscal year-end.

These institutional factors mean that, in the year of an auditor change, it is likely that the predecessor auditor would have already done some of the work in preparation for the year-end audit. The amount of work by the predecessor auditor is likely to be greater when the successor auditor is appointed later in the year. For example, suppose a company's fiscal year stretches from January $1^{\text {st }} 20 \times 5$ to December $31^{\text {st }} 20 \times 5$. The amount of work done by the predecessor auditor would be zero if the successor auditor is appointed on January $1^{\text {st }} 20 \times 5$; the work done by the predecessor auditor would likely be significant if the successor auditor is appointed on October $31^{\text {st }} 20 \times 5$ (i.e., ten months into the fiscal year); and, the work done by the predecessor auditor would likely be very substantial if the successor auditor is appointed sometime after the fiscal yearend (say January $15^{\text {th }} 20 \mathrm{x} 6$ ).

To the extent that the procedures undertaken by the predecessor auditor are necessary for the annual audit, this will likely result in a duplication of audit effort and an increase in the combined audit fee paid to the successor and predecessor. For example, if the predecessor auditor is replaced in the Fall of 20x5 having already tested the effectiveness of the company's internal controls during the first six months of the fiscal year $(1 / 1 / 20 \times 5-6 / 30 / 20 \times 5)$, there would be a duplication of audit effort because the successor auditor would also need to assess whether internal controls were operating effectively during the first six months of the fiscal year. This duplication of effort means that the combined fee paid to the predecessor and successor auditors is likely to be relatively high during the auditor change year. Unfortunately, however, the SEC does not require auditor change companies to disclose the combined fee. Instead, auditor change companies are only required to disclose the fee paid to the successor auditor. 
While the duplicated efforts of predecessor and successor auditors tend to increase their combined fee, the fee paid to the successor auditor alone tends to be biased downwards because the successor auditor typically performs services for just a partial year. The SEC's definition of the annual audit fee includes any fees paid for quarterly reviews. Quarterly reviews do not have to be re-performed by the successor auditor if they were already performed by the predecessor auditor prior to the auditor change. For example, if the predecessor auditor is replaced in September of 20x5 having already reviewed the quarterly financial statements for the first two quarters of the fiscal year $(1 / 1 / 20 \times 5-6 / 30 / 20 \times 5)$, there would be no need for the successor auditor to repeat these earlier reviews. Instead, the successor auditor would review the interim financial statements for the third quarter and perform the year-end audit. This means that the fee paid to the successor auditor in the year of the auditor change is generally for a partial year of services rather than a full year. Thus, the fee paid to the successor auditor is biased downwards relative to the no-change observations in which the incumbent auditor performs all of the quarterly reviews as well as the year-end audit.

In summary, we expect that the combined audit fee paid to the successor and predecessor auditors is relatively high because the successor auditor has to duplicate some of the procedures that were already performed by the predecessor auditor prior to the auditor change date. In contrast, we expect that the audit fee paid to the successor auditor alone is biased downwards because the successor auditor provides services for a partial year only. The challenge facing the users of audit fee disclosures is that most auditor change companies disclose only the audit fee paid to the successor auditor because they are not required to disclose the fee paid to the predecessor. Unfortunately, prior research has not distinguished between these two situations and this has caused significant bias in the measurement of audit fees during an auditor change year. 


\subsection{Prior research}

Early empirical studies report evidence of significant fee discounting in initial year audit engagements (Simon and Francis 1988; Ettredge and Greenberg 1990). Over the past 30 years, this finding has proved to be one of the most enduring and robust results in the auditing literature, with dozens of studies reporting that audit fees are significantly lower when there is a change of audit firm (Hay 2006).

To assess the recent evidence, we reviewed every audit fee study published between 20112018 in six accounting journals (Auditing: A Journal of Practice \& Theory, Contemporary Accounting Research, Journal of Accounting Research, Journal of Accounting and Economics, The Accounting Review, and Review of Accounting Studies). We found 34 studies that use data from the United States and that report tests for fee differences in initial year audits. The 34 studies are summarized in Table 1.

\section{[INSERT TABLE 1 HERE]}

Of the 34 studies, we find that 27 report fee discounts that are statistically significant at the $5 \%$ level or better. Six studies report insignificant fee discounts (but in some cases the lack of significance could be attributable to small samples and low power tests). Only one study reports that audit fees are significantly higher during the auditor change year (Kim et al. 2015). Interestingly, the estimated coefficients for the auditor change variables vary tremendously across the 34 studies suggesting significant measurement issues. For example, the auditor change coefficient is equal to -0.034 in Bruynseels and Cardinaels (2014) but is more than ten times larger $(-0.548)$ in Numan and Willekens (2012). We demonstrate in our replication analysis that the 
variation in coefficient size is largely attributable to the different methods that studies have used to measure audit fees during the auditor change year.

None of the studies in Table 1 disclose how they measure audit fees during the auditor change year. This lack of disclosure is not surprising because the primary objective of most of these studies is not to test whether there is fee discounting in initial year audits. Instead, most studies include the auditor change variable simply as a control variable. Given the lack of complete information in the published articles, we contacted the authors to find out how they measured audit fees during the auditor change year. We received usable responses from the authors of 31 studies. ${ }^{10}$

The responses indicate that 24 studies used only the fee paid to the successor auditor. One study used the fee paid to the predecessor auditor (where this was disclosed) and used the fee paid to the successor auditor (where the predecessor's fee was not disclosed). Two studies used the higher of the two audit fees in cases where the predecessor's fee was disclosed and they used the fee paid to the successor auditor where the predecessor's fee was not disclosed. Finally, four studies used the combined fee paid to the successor and predecessor auditors in cases where the predecessor's fee was disclosed, and in the remaining auditor change observations they used the fee paid to the successor auditor. Overall, these statistics imply that 27 studies used either the fee paid to the successor auditor or the fee paid to the predecessor auditor, whereas four studies used the combined fees in cases where the predecessor's audit fee was disclosed. ${ }^{11}$

\footnotetext{
${ }^{10} \mathrm{We}$ are extremely grateful to the authors who often went to extraordinary lengths to provide accurate responses to our questions. In several cases, the authors spent time reviewing their programming code in order to give us reliable answers.

${ }^{11}$ In Audit Analytics, the combined fee paid to the successor and predecessor auditors is shown as a single row of data in the auditor changes data file. In other data files, Audit Analytics shows the fees paid to the successor and predecessor auditors as two separate rows of data. This different data structure may explain why studies have used different approaches to measuring audit fees during the auditor change year. We thank Professor Yongtae Kim for bringing this to our attention.
} 
Next, we investigate whether these different approaches to measuring audit fees help to explain the variation in the estimated strength of initial year fee discounting in prior literature. Of the four studies that use the combined fee measure, we find that only two report significant evidence of fee discounting while one study finds that audit fees are significantly higher during the auditor change year (Kim et al. 2015). The evidence of initial year fee discounting is therefore mixed among the studies that commingle the combined fee with the fee paid to the successor auditor. In contrast, the evidence of fee discounting appears to be much stronger among the 27 studies that use either the fee paid to the successor auditor or the fee paid to the predecessor auditor. Of these 27 studies, we find that 23 ( 85 percent) report fee discounts during the auditor change year that are statistically significant at the $5 \%$ level or better. This suggests that the evidence of initial year fee discounting is more prevalent when researchers use only one of the two fee measures, which is what most studies in the literature have done.

\section{Sample and descriptive statistics}

Our sample covers the period from 2004 to 2015 . We begin in 2004 because this is when the SEC expanded the nature of services for which the related fees could be categorized as "audit fees" (SEC 2003a), and because this is when Section 404 of SOX became applicable. Our sample ends in 2015 because we require data on subsequent restatements and most restatements happen within three years of the original financial statements. We obtain audit data from Audit Analytics and financial data from Compustat.

Table 2 outlines our sample selection process. We begin by merging the Audit Analytics data on audit fees, audit opinions, and auditor changes with observations in the Compustat database. To identify auditor change observations, we require that the new auditor signs the audit 
opinion for the year-end financial statements and the new auditor is appointed in the period from the beginning of the fiscal year to within 60 days after the fiscal year-end. Consistent with prior research, we delete companies in the financial sector (SIC codes 6000-6999), companies registered in foreign countries, and observations with total assets less than $\$ 1$ million. After deleting another 681 observations with missing data for the control variables, we are left with a final sample of 46,970 observations. The final sample includes 3,102 auditor change observations $(6.6 \%$ of the overall sample).

\section{[INSERT TABLE 2 HERE]}

Table 3 provides information about the sample distribution. Panel A shows that $62 \%$ of auditor change companies disclose only the fee paid to the successor auditor, while $38 \%$ disclose the fee paid to the predecessor auditor as well as the fee paid to the successor. These percentages show little variation over time, suggesting that there have not been any trends in fee disclosures during the sample period.

\section{[INSERT TABLE 3 HERE]}

Panel B of Table 3 provides information about the timing of the successor auditor's appointment. We find that most successor auditors are appointed in the latter half of the fiscal year or after the fiscal year-end. In addition, companies are more likely to disclose the fee paid to the predecessor auditor if the successor is appointed during the second quarter or thereafter. This makes intuitive sense because the fee paid to the predecessor auditor is likely to be more substantial if the successor auditor is appointed later in the fiscal year or after the fiscal year-end. Nevertheless, there is a non-trivial amount of non-disclosure even when the successor auditor is appointed very late in the year. For example, only $40 \%$ of auditor change companies disclose the fee paid to the predecessor auditor even when the successor is appointed after the fiscal year-end. Overall, these 
findings suggest that most auditor change observations represent partial-year services by the successor auditor and companies usually do not disclose the fees paid to the predecessor for services performed prior to the appointment of the successor auditor.

Panel $\mathrm{C}$ of Table 3 shows the proportion of fees paid to the successor auditor when the sample is restricted to companies that disclose both the fee paid to the predecessor as well as the fee paid to the successor. The statistics suggest that the amount of work done by the successor auditor is declining the later in the year that the successor auditor is appointed. For example, the mean (median) proportion of fees paid to the successor auditor is $78 \%(83 \%)$ when the successor auditor is appointed during the first fiscal quarter whereas it falls to $59 \%(63 \%)$ when the successor auditor is appointed during the fourth fiscal quarter. These findings suggest that predecessor auditors do more work during the auditor change year when successor auditors are appointed later in the year.

Table 4 reports descriptive statistics for the auditor change and no-auditor-change observations. As discussed in Section 2.3, prior studies use different approaches when measuring audit fees during the auditor change year. Most studies measure the fee paid to the successor auditor only. Following this approach, our first audit fee variable (AF1) captures only the fee paid to the successor auditor when the observation is an auditor change year. A less common approach is to measure the audit fee as the fee paid to the successor auditor if the company discloses only the fee paid to the successor auditor, and to measure it as the fee paid to the predecessor auditor if the company discloses both fees. Following this approach, our second audit fee variable (AF2) captures the fee paid to the successor auditor if the company discloses only the fee paid to the successor auditor whereas it captures the fee paid to the predecessor auditor if the company discloses both. A third approach, used by some studies, is to measure the fee paid to the successor 
auditor if the company discloses only the fee paid to the successor, and to measure the higher of the two fees if the company discloses both fees. We follow this approach as well, which gives us our third audit fee variable (AF3). Finally, some studies measure the fee paid to the successor auditor if the company discloses only the fee paid to the successor auditor, while they measure the combined audit fees if the company discloses the fee paid to the predecessor as well as the fee paid to the successor. This is our fourth audit fee variable (AF4).

\section{[INSERT TABLE 4 HERE]}

In the auditor change sample, we find that the combined audit fee variable (AF4) is larger than the other three fee variables. In particular, the median value of $A F 4$ is $\$ 286,598$, whereas the median values of $A F 1, A F 2$, and $A F 3$ are $\$ 243,039, \$ 162,136$, and $\$ 257,821$, respectively. Thus, the differences in audit fees can be as large as 76.8 percent (AF4 versus AF2). Moreover, these descriptive statistics suggest that the downward bias is greater when researchers use only the fee paid to the predecessor or successor auditor, rather than both fees combined. The downward bias is largest when the fee is measured using the fee paid to the predecessor auditor (AF2), which makes intuitive sense because most of the work during the auditor change year is done by the successor auditor because it is the successor who signs the year-end audit report. Therefore, the fee paid to the predecessor auditor, when taken on its own, is a particularly poor proxy for the fullyear audit fee.

The mean values of the control variables are generally in line with those reported in prior studies. Consistent with prior studies, we find that auditor-change companies are smaller than nochange companies. Further, the change companies are less profitable and are more likely to receive a going-concern opinion. The change companies are less likely to have a Big 4 (successor) auditor and are more likely to have a material weakness in internal controls. 


\section{Results}

\subsection{Replicating prior research}

We begin our regression analysis by replicating the approaches taken in prior research. Specifically, we estimate audit fee models in which the dependent variables capture the four alternative approaches that prior studies have used to measure logged audit fees during the auditor change year (i.e., $L A F 1, L A F 2, L A F 3$ and $L A F 4$ ). We expect that all four approaches result in biased estimates of initial year fee discounting because they all suffer from the problem that the majority of companies do not disclose the fee paid to the predecessor auditor. On the other hand, we expect that the first three variables ( $L A F 1, L A F 2, L A F 3)$ produce the most biased estimates because these variables do not combine the fees paid to the successor and predecessor auditors (in cases where both fees are disclosed) and so their fee variables in the auditor change year capture only a partial year of services. Our variable of interest is the indicator variable, INITIAL, which takes the value one for auditor change observations (zero otherwise).

Following prior audit fee research, our regressions control for client size and other audit engagement characteristics such as client complexity, profitability, audit risk, auditor type, and audit opinion. The Appendix provides a full list of the control variables and their definitions. We include year fixed effects to control for temporal variation in audit fees during our sample period. In addition, we report audit fee regressions with and without controls for company fixed effects. We report results without company fixed effects because most audit fee studies do not control for them and we wish to make our results more comparable to prior research. However, we also report regressions with company fixed effects because the auditing literature is increasingly moving towards using panel data approaches to control for unobserved heterogeneity among audit clients. 
The results are reported in Table 5. Panel A shows the specifications with company fixed effects while Panel B shows the specifications without company fixed effects. In both panels, Column (1) shows the results when the dependent variable is LAF1 (i.e., the audit fee variable during the auditor change year captures only the fee paid to the successor auditor). Consistent with the prior evidence on initial year fee discounting, Column 1 shows highly significant negative coefficients on the INITIAL variable (t-stats. $=-18.73,-15.32$ in Panels A and $\mathrm{B}$, respectively). In Column (2), we switch to using the second measure of audit fees (LAF2), where the fee variable during the auditor change year captures the fee paid to the predecessor auditor (where this is disclosed) or the fee paid to the successor auditor (where the predecessor's fee is not disclosed). We expect that this variable has the most downward bias because the fee paid to the predecessor auditor is typically much smaller than the fee paid to the successor auditor (see Table 4) because most of the audit work is done by the successor auditor. Consistent with this, we find that the negative coefficients on the INITIAL variable are more than twice as large in Column (2) compared to Column (1). The results for initial fee discounting are strongest in Column (2) (t-stats. $=-30.73$, -29.35) because this is the specification in which audit fees are biased downwards to the greatest extent during the auditor change year.

\section{[INSERT TABLE 5 HERE]}

Column (3) shows the results for the third measure of audit fees (LAF3), where the fee variable during the auditor change year captures the higher of the fees paid to the successor auditor and predecessor auditor (if the predecessor's fee is disclosed), or the successor's audit fee (if the predecessor's fee is not disclosed). We expect the bias is smaller in Column (3) than in Columns (1) and (2) because the LAF3 variable captures the larger of the two fees in observations where both fee variables are disclosed. Consistent with this, we find that the coefficients on INITIAL are 
less negative in Column (3) than Columns (1) and (2) although they are still highly significant (tstats. $=-14.81,-11.57)$

Finally, Column (4) shows the results for the fourth measure of audit fees (LAF4), where the fee variable during the auditor change year captures the sum of the fees paid to the successor and predecessor auditors (if the predecessor's fee is disclosed), or the successor's audit fee (if the predecessor's fee is not disclosed). We expect the bias to be smaller in Column (4) than the other columns because the LAF4 variable captures both fee measures in the subset of auditor change observations where this information is publicly disclosed. Consistent with this, we find that the coefficients on INITIAL are much smaller in Column (4) although they are still significant at the $5 \%$ level (t-stats. $=-2.51,-2.39)$.

Overall, the results in Table 4 replicate the evidence in the prior literature that there is significant fee discounting in initial year audits. Moreover, we show that the estimated magnitude of the fee discounting is strongly influenced by the way in which audit fees are measured during the auditor change year. Similar to prior research, we find that the coefficients on INITIAL in Table 5 vary tremendously, from -0.59 in Column (2) to -0.02 in Column (4), suggesting that the audit fee measurement approach has a major impact on the estimated magnitude of fee discounting. Although LAF4 is the least contaminated of the four fee variables (Column (4)), we expect that all four approaches are biased because they all depend to varying degrees upon the fees paid to the successor auditor for a partial year of services. In the next section, we explore alternative approaches to removing the bias in order to determine whether audit fees really are discounted in initial year audit engagements.

\subsection{Testing for the presence of initial year fee discounting after removing the bias}


The estimates of fee discounting are biased because audit fees during the auditor change year typically represent partial-year services by the successor auditor. Our first approach to addressing this problem is to focus on auditor change companies that disclose fees for both the predecessor and successor auditors. Specifically, we measure audit fees using the combined fee variable (LAF4) and we drop the 1,923 auditor change observations where the company does not disclose the fee paid to the predecessor auditor. Thus, the auditor change sample in this specification comprises 1,179 companies that report the fees paid to both auditors and the dependent variable (LAF4) captures the sum of these fees.

As discussed in Section 2.3, it is likely that the predecessor auditor would have already done some of the work that is necessary for the year-end audit prior to the auditor change date and that the successor auditor would have to duplicate some of these audit procedures in order to render an audit opinion. To the extent that the auditor change results in a duplication of audit effort, we would expect the combined fee paid to the predecessor and successor auditor to be higher than the fee that is paid to the incumbent auditor when there is no auditor change. The results are reported in Column (1) of Table 6. Consistent with the auditor change resulting in a duplication of audit effort, we find a significant positive coefficient on the INITIAL variable (t-stat. $=4.44)$. The coefficient on the INITIAL variable indicates that initial year audits are associated with a fee premium of about 6.5 percent. Therefore, the combined fee paid to the predecessor and successor auditors during the auditor change year is significantly larger than the fee that is paid when there is no change of auditor. This makes intuitive sense given that some of the procedures performed by the predecessor auditor prior to the auditor change date would likely have to be repeated by the successor auditor as part of the annual audit.

[INSERT TABLE 6 HERE] 
A limitation of Column (1) is that we drop the auditor change companies that do not voluntarily disclose the fee paid to the predecessor auditor, which raises potential concerns about selection bias. In addition, the literature on initial year fee discounting is primarily concerned with the pricing strategy of the successor auditor rather than the combined fee paid to the successor and predecessor auditors. To address both limitations, we examine the fee paid to the successor auditors in the first full-year audit. For example, if the successor auditor is appointed in November 20x5 and audits the financial statements with a fiscal year-end of December 20x5, the following year (20x6) would correspond to the successor auditor's first full-year audit. The first full-year fee is a reasonable approximation to the fee that would have been paid in the auditor change year if the successor auditor had been appointed at the start of the fiscal year because audit firms often negotiate multi-year contracts with their clients which means that audit fees tend to be sticky from one year to the next (Ferguson et al. 2005; Ramos 2012; de Villiers et al. 2014).

The NEXT variable equals one for the first full-year audit by the successor auditor following the auditor change (zero otherwise). The sample for this test excludes all of the auditor change observations, which means that the four audit fee variables $(L A F 1=L A F 2=L A F 3=$ LAF4) have exactly the same values (their values differ only among the auditor change observations). The NEXT variable captures any difference in audit fees between the first full-year audit by the successor auditor and all other no-change observations. The results for this specification are reported in Column (2) of Table 6. The coefficient on NEXT is positive (0.0007) but statistically insignificant $(\mathrm{t}$-stat. $=0.08)$. Therefore, the fee paid to the successor auditor is not significantly different in the year subsequent to the auditor change.

A limitation of Column (2) is that we drop all of the auditor change observations, which means that we cannot draw inferences about the fee charged by the successor auditor during the 
auditor change year. This is problematic to the extent that the fee in the first full-year audit is not a good proxy for the fee that the successor auditor would have received if the successor had been appointed at the start of the auditor change year. To address this concern, we empirically estimate the magnitude of the downward bias in the fee paid to the successor during the auditor change year. We expect that the bias is an increasing function of the length of time between the start of the fiscal year and the date that the successor auditor is appointed. To put this another way, we would not expect any bias if the successor auditor were hired at the start of the fiscal year because that would represent a full-year audit.

We estimate the magnitude of the bias by estimating the following model:

$L A F 1=\mathrm{a}+\mathrm{b} I N I T I A L+\mathrm{c} I N I T I A L \times L D A Y S+C O N T R O L S+\mathrm{u}$

The dependent variable (LAF1) captures the fee paid to the successor auditor during the auditor change year. The definition of INITIAL is the same as earlier. The LDAYS variable is the natural $\log$ of the number of days from the beginning of the fiscal year until the date of the successor auditor's appointment. The INITIAL $\times$ LDAYS variable controls for the downward bias that is attributable to the successor auditor being appointed later than the start of the fiscal year. We expect a negative coefficient for the INITIAL $\times$ LDAYS variable because the fee paid to the successor auditor is biased downwards to a greater extent, the later that the successor auditor is appointed. The coefficient on INITIAL captures the fee difference in initial year audits when the successor auditor is appointed at the start of the fiscal year; i.e., when LDAYS is equal to zero. Therefore, the INITIAL variable captures the 'true' pricing behavior of the successor auditor after controlling for the downward bias arising from partial-year audits. If the successor's audit fee is discounted, as most of the prior literature claims, we would expect a negative coefficient on the INITIAL variable. In contrast, a significant positive coefficient on INITIAL would mean that the 
successor's audit fee is higher when the successor is appointed at the beginning of the fiscal year. A positive coefficient on INITIAL would make intuitive sense because the successor auditor incurs significant start-up costs when auditing a client for the very first time.

The results for eq. (1) are reported in Col. (3) of Table 6. We find that the INITIAL $\times$ LDAYS coefficient is significantly negative (t-stat. $=-3.90)$, which means that the fee paid to the successor auditor is significantly lower when the appointment date is farther away from the beginning of the fiscal year. This supports our argument that the successor's fee is biased downwards as a result of partial-year audits. In contrast, we find a significant positive coefficient on the INITIAL variable $(t-s t a t .=1.72)$. The coefficient estimate $(0.1435)$ implies that the fee paid to the successor auditor is approximately 15.4 percent larger in the year of the auditor change. This suggests that the audit fees of successor auditors are higher rather than lower after we adjust for the downward bias arising from later appointments. The estimated premium of 15.4 percent suggests that the additional startup costs incurred by successor auditors are likely to be significant.

We use the results in Column (3) to calculate what the successor's fee would have been if the successor had been appointed right at the beginning of the fiscal year. We call this our estimate of the successor auditor's 'corrected' full-year audit fee (LAF1_Corr). Specifically, the successor's corrected full-year fee is calculated as follows:

LAF1_Corr $=L A F 1-\hat{c} I N I T I A L \times$ LDAYS

Because $\hat{c}$ is estimated to be negative $(-0.0653)$ in Column (3), this calculation adds back the downward bias that arises due to the successor auditor being appointed after the beginning of the fiscal year. In other words, there is no bias in the disclosed fee when the successor is appointed right at the start of the fiscal year; i.e., LAF1_Corr $=L A F 1$ when $L D A Y S=0$. We find the mean (median) value for the successor auditor's corrected full-year fee (AF1_Corr) is $\$ 889,739$ 
$(\$ 338,716)$ whereas the mean (median) value for the successor's disclosed partial-year fee $(A F 1)$ is $\$ 643,927(\$ 243,039)$. Therefore, there is a substantial downward bias in the disclosed fee arising from partial-year audits.

Column (4) of Table 6 reports the results using LAF1_Corr as the dependent variable. We find a significant positive coefficient on the INITIAL variable. The coefficient estimate $(0.1411)$ implies that the fee paid to the successor auditor is approximately 15.2 percent higher in the year of the auditor change, which is very similar to the 15.4 percent estimate found in Column (3). The t-statistic on the INITIAL coefficient is larger in Column (4) (t-stat. = 13.66) than in Column (3) because there is no interaction variable (INITIAL $\times$ LDAYS) in Column (4). In Column (3), the interaction variable (INITIAL $\times$ LDAYS) is highly correlated with the INITIAL variable, which causes the standard error on the INITIAL coefficient to become inflated and the t-statistic to become deflated (t-stat. $=1.72) .{ }^{12}$

\subsection{Testing the association between audit quality and initial year fee discounting}

The results in Table 6 suggest no fee discounting for the average auditor change company. Nevertheless, it is possible that some auditor change companies receive discounted fees but their fee discounts are offset by increased fees at other auditor change companies. This is potentially important because regulators have raised concerns that fee discounting, when it occurs, could result in impaired audit quality. Although the average auditor change company does not receive a fee discount, it is possible that some companies do receive such discounts and that this leads to lower quality auditing.

\footnotetext{
12 The variance-inflation-factors for INITIAL and NEXT are below ten in Columns (1), (2), and (4), whereas the variance-inflation-factors for INITIAL and INITIAL $\times$ LDAYS exceed twenty in Column (3).
} 
To examine this, we use our estimate of the successor's corrected fee (LAF1_Corr) to identify which companies receive discounted (elevated) fees from their successor auditors during the auditor change year. We identify the successor's full-year audit fee as discounted (elevated) if the corrected fee (LAF1_Corr) is less (greater) than the expected fee, where the expected fee is predicted using the coefficient estimates shown in Column (4) of Table 6. Specifically, we code the audit fee as discounted (DISCOUNT $=1)$ if the audit fee residuals in Column $(4)$ of Table 6 are negative (zero if the residuals are positive).

We test the association between audit quality and initial year fee discounting by estimating variants of the following model:

Audit qual. $=\mathrm{a}+\mathrm{b}$ INITIAL $+\mathrm{c}$ DISCOUNT $+\mathrm{d}$ INITIAL $\times$ DISCOUNT + CONTROLS $+\mathrm{v}$

We estimate eq. (2) using multiple measures of audit quality as dependent variables. Specifically, we use subsequent accounting restatements, going-concern audit reports, auditors' SOX 404 internal control reports, and four different metrics of abnormal accruals. The RESTATE variable equals one if there is a subsequent restatement of the annual financial statements (zero otherwise). The $G C$ variable equals one if the auditor issues a going-concern opinion in the audit report (zero otherwise). The $M W$ variable equals one if the auditor's SOX 404(b) opinion discloses a material weakness in internal controls over financial reporting (zero otherwise). We measure abnormal total accruals (ATA) using the modified Jones model (Dechow et al. 1995). We also use abnormal current accruals (ACA) because prior studies suggest that managers have more flexibility to manipulate earnings with current accruals compared to long term accruals (Bradshaw et al. 2001; Ashbaugh et al. 2003). Finally, we use performance-matched abnormal total accruals (PMATA) and performance-matched abnormal current accruals (PMACA) as suggested by Kothari et al. (2005). Our variable of interest is the interaction term, INITIAL $\times$ DISCOUNT, which captures 
whether the association between audit quality and fee discounting is significantly different in initial year audits. If fee discounting in initial year audits is associated with lower audit quality, we would expect more accounting restatements, fewer going-concern opinions, fewer adverse internal control opinions, and larger abnormal accruals.

The control variables in the restatement model are based on prior studies (Doyle et al. 2007; Romanus et al. 2008; Badolato et al. 2014). Specifically, we control for company size (LTA), profitability (ROA and LOSS), leverage (LEV), client complexity (SQSEG), and external financing (FINANCE). We include company random effects rather than company fixed effects because the fixed effects specification would cause significant sample attrition by discarding all of the companies that experience no variation in the dependent variable (RESTATE) during the sample period. In addition, we control for yearly variation in accounting restatements by including year fixed effects. Following DeFond and Lennox (2011), the control variables in the model of goingconcern opinions include client size (LTA), liquidity (LIQ), leverage (LEV), a loss dummy (LOSS), and auditor size (BIG4). As with the restatement model, we also include year fixed effects and company random effects. The control variables in the model of internal control opinions $(M W)$ are based on prior studies (Doyle et al 2007; Ogneva et al. 2007). We control for company size (LTA), auditor size (BIG4), a loss dummy (LOSS), foreign operations (FOREIGN), extreme sales growth (EXTREME_SALES), financial distress (RZSCORE), and restructuring (RESTRUCTURE), as well as year fixed effects and company random effects. The $M W$ model is estimated using the subsample of observations that receive internal control opinions from their auditors. Our accrual models follow prior research on the determinants of abnormal accruals (see Healy and Wahlen (1999) for a review). We control for company size (LTA), profitability (ROA and LOSS), leverage (LEV), financial distress (RZ_SCORE), sales growth (GROWTH), external financing (FINANCE), 
client complexity (SQSEG), foreign operations (FOREIGN), restructuring (RESTRUCTURE), an indicator for extraordinary items (EXTORD), and auditor size (BIG4). In addition, the accrual models include company fixed effects and year fixed effects.

The results are reported in Table 7 . The coefficients on INITIAL $\times$ DISCOUNT are insignificant in the models of restatements, going-concern opinions, and internal control reports. These results suggest that the relation between audit quality and fee discounting is not significantly different in initial year audits. The coefficients on DISCOUNT are significantly negative in the restatements model (z-stat. $=-1.70)$, insignificant in the going-concern model, and significantly positive in the model of internal control opinions $(z$-stat. $=1.93)$. Although these results are weak, they suggest that fee discounting is positively related to audit quality when companies do not change auditor. Overall, these results provide no evidence that fee discounting is linked to low audit quality.

\section{[INSERT TABLE 7 HERE]}

The coefficients on INITIAL $\times$ DISCOUNT are significantly negative in the models of abnormal total accruals $(A T A)$ and abnormal current accruals $(A C A)($ t-stats. $=-2.21,-2.32)$. This suggests a more negative relation between abnormal accruals and fee discounting during initial year audits. However, this result loses statistical significance when the dependent variables are measured using performance-matched abnormal total accruals (PMATA) and performancematched abnormal current accruals $(P M A C A)(\mathrm{t}-\mathrm{stats} .=-1.37,-1.50)$. Overall, then, our results provide no evidence that audit quality is lower when fees are discounted in initial year audits.

\subsection{Additional analyses}

4.4.1 The reliability of audit fee disclosures 
SEC rules specify that a company is only required to disclose the fee paid to the opining (successor) auditor during the year of an auditor change. Nevertheless, it is possible that registrants are either unaware of this rule or erroneously include fees paid to the predecessor auditor in the fee that is reported for the successor auditor. ${ }^{13}$ Hence, we perform sensitivity analysis by restricting the auditor changes sample to companies that separately disclose the fees paid to both the predecessor and successor auditors. Because these companies are disclosing the two fees separately, it is unlikely that they would have included the predecessor's fee in the reported fee paid to the successor auditor.

We exclude the companies that do not disclose the fees paid to the predecessor auditor and re-estimate the model reported in Column (3) of Table 6. We continue to find no evidence of fee discounting in initial year audits. The coefficient on INITIAL is positive but insignificant (coeff. = 0.229 , t-stat. $=1.17$ ) while the coefficient of INITIAL $\times$ LDAYS is negative and significant (coeff. $=-0.116$, t-stat. $=-3.12$ ), showing that the successor's disclosed audit fee is biased downwards due to the effect of partial-year audits. Next, we use these estimates to obtain a revised estimate of the corrected full-year fee paid to the successor auditor (LAF1_Corr) and re-estimate the model reported in Column (4) of Table 6. We continue to find that audit fees are substantially higher in initial year audits. The estimated coefficient on INITIAL is $0.229(\mathrm{t}-\mathrm{stat} .=12.48)$.

Next, we re-perform each of the audit quality analyses. We continue to find that the coefficients on INITIAL $\times$ DISCOUNT remain insignificant in the models for restatements $(\mathrm{z}$-stat. $=-0.94)$, going-concern opinions $(z-s t a t .=1.37)$, and internal control opinions $(z$-stat. $=0.78)$. In

\footnotetext{
${ }^{13}$ Mitigating such fee disclosure errors is the fact that such disclosures are subject to verifications during PCAOB inspections. Further, while compliance with fee disclosure rules may have been relatively lax in the initial years, after a series of Wall Street Journal stories about problems in the fee disclosures by Healthsouth, the SEC initiated an enquiry (SEC 2003b). Anecdotal evidence from audit partners also suggests that fee disclosures were scrutinized much more after 2003 .
} 
addition, the INITIAL $\times$ DISCOUNT coefficients are insignificant in the regressions for abnormal total accruals (t-stat. $=-0.74)$, abnormal current accruals $(\mathrm{t}$-stat. $=-0.55)$, performance-matched abnormal total accruals ( $\mathrm{t}$-stat. $=-0.27)$, and performance-matched abnormal current accruals ( $\mathrm{t}$ stat. $=-0.10)$

\subsubsection{Client dismissals versus auditor resignations}

Prior studies have shown that client-initiated auditor dismissals are quite different from auditorinitiated resignations (DeFond et al. 1997; Krishnan and Krishnan 1997; Whisenant et al. 2003). ${ }^{14}$ Our sample of 3,102 auditor changes has 2,294 dismissals and 808 resignations (886 dismissals and 293 resignations for companies that disclose both predecessor and successor fees). We therefore examine whether the evidence for fee discounting is different for dismissals compared to resignations. We do this by replacing the INITIAL dummy variable with two alternative indicators, INITIAL_DISMISS and INITIAL_RESIGN, where the former captures auditor dismissals while the latter captures auditor resignations. When we re-estimate Col. (1) of Table 6 we find that both coefficients are positive and significant; specifically, the coefficient on INITIAL_DISMISS is 0.045 (t-stat. $=2.88)$ while the coefficient on INITIAL_RESIGN is $0.123(\mathrm{t}-$ stat. $=4.00)$. Next, we create two new indicators, NEXT_DISMISS and NEXT_RESIGN, which capture the first full-year under the successor auditor following a dismissal or a resignation. When we re-estimate Col. (2) of Table 6 we find that companies that dismissed their auditors in the prior year have approximately $2 \%$ lower audit fees $(\mathrm{t}$-stat. $=-1.96)$ while companies that had their auditor resign in the prior year have higher audit fees $(\mathrm{t}$-stat. $=3.54)$. While the coefficient on NEXT_DISMISS is negative, its magnitude $(-0.020)$ is quite small and is more than offset by the

\footnotetext{
${ }^{14}$ See, for example, DeFond et al. (1997), Krishnan and Krishnan (1997), and Whisenant et al. (2003).
} 
higher fees paid by dismissal companies during the year of the auditor change. Therefore, this finding does not appear to provide evidence of initial-year fee discounting. Next, we create two interaction variables, INITIAL_DISMISS $\times$ LDAYS and INITIAL_RESIGN $\times$ LDAYS, in order to estimate the downward bias in successor audit fees during the years of auditor dismissals and resignations. When we re-estimate Col. (3) of Table 6 we find that the coefficient on INITIAL_DISMISS is positive but not significant $(\mathrm{t}$-stat. $=1.15)$ while the coefficient on INITIAL_RESIGN is positive and significant $(\mathrm{t}$-stat $=2.12)$. Crucially, the coefficients on the two interaction variables are both negative and significant (t-stats $=-3.10,-2.95)$, suggesting that the downward bias in the successor's audit fee does not depend on which party decided to terminate the previous auditor-client arrangement. Last, we obtain an updated estimate of the successor's corrected audit fee (LAF1_Corr) and regress this fee on INITIAL_DISMISS and INITIAL_RESIGN. Consistent with the results in Column 4 of Table 6 , we find that the coefficients on both INITIAL_DISMISS and INITIAL_RESIGN are positive and highly significant (t-stats. $=11.21$, 7.84), implying that the successor's full-year audit fee is higher for both auditor dismissals and auditor resignations.

Next, we use the residuals from Col. (4) of Table 6 to identify cases of fee discounting in auditor dismissals (DISCOUNT_DISMISS) and resignations (DISCOUNT_RESIGN). When we reestimate the audit quality models in Table 7, we find that the coefficients on both DISCOUNT_DISMISS and DISCOUNT_RESIGN are statistically insignificant for restatements, going concerns, and material weaknesses. We also find that the coefficient on DISCOUNT_DISMISS is statistically insignificant in all four abnormal accruals specifications, while the coefficient on DISCOUNT_RESIGN is negative and significant in all but the performance-matched abnormal accruals specification. Consistent with Table 7, these results 
provide no evidence that fee discounting during the auditor change year is associated with lower quality auditing.

\section{Conclusions}

Audit fees in initial year audit engagements have been of significant interest to regulators and researchers due to concerns that low-priced audits by successor auditors result in lower quality audits. The results of many empirical studies appear to show that there is significant audit fee discounting in initial year audits but, in this paper, we show that the findings are attributable to significant measurement bias. The bias arises because SEC rules require auditors to review clients' quarterly filings but the auditor change company is only required to disclose the fee paid to the auditor who renders an opinion on the year-end financial statements (SEC 2001, 2003a). Consequently, the predecessor auditor often does a substantial amount of work prior to the auditor change date and is compensated for rendering those services but the fee paid to the predecessor auditor is usually not disclosed. Instead, the disclosed fee during the auditor change year is usually for a partial-year of services performed by the successor auditor. The majority of auditor changes occur well after the first fiscal quarter, which exacerbates the magnitude of the bias. After correcting for the downward bias in the successor's partial-year audit fee, we find that there is no evidence of fee discounting in initial year audit engagements. To the contrary, our findings suggest that, if anything, audit fees are significantly higher during the auditor change year.

We test for an association between audit quality and fee discounting in initial year engagements after adjusting for the downward bias in the fees paid to successor auditors. We measure audit quality using accounting restatements, going-concern audit opinions, SOX 404(b) internal control audit opinions, and four different metrics of abnormal accruals. We consistently 
find no evidence of audit quality being impaired as a result of fee discounting in initial year audit engagements. The longstanding concerns of legislators and regulators are based on a belief that fee discounting can create pressures for auditors to cut corners in their work. Our results suggest an alternative explanation for the findings of prior research. In particular, the fee paid to the successor auditor is biased downwards because some of the work during the auditor change year has already been done by the predecessor auditor and the fee paid to the predecessor is generally not disclosed.

Our inferences are subject to an important caveat. Similar to most studies in the literature, we do not have data on audit costs and, hence, we are unable to measure audit engagement profitability. Although we observe no evidence of fee discounting in initial year audits when using a standard model of audit fees, it is possible that the fees charged by successor auditors are less than their true costs. Nevertheless, our audit quality tests should help to assuage the concerns of regulators that initial year fee discounting is linked to low quality auditing. 


\section{References}

Albrecht, A., Mauldin, E. G., Newtonm and N. J., 2018. Do auditors recognize the potential dark side of executives' accounting competence? The Accounting Review 93(6): 1-28.

American Institute of Certified Public Accountants (AICPA), 1978. Commission on Auditors' Responsibilities: Report, Conclusions, and Recommendations. New York, NY: AICPA.

Ashbaugh, H., LaFond, R., Mayhew, B., 2003. Do non-audit services compromise auditor independence? The Accounting Review 78(3): 611-639.

Badertscher, B., Jorgensen, B., Katz, S., Kinney, W., 2014. Public equity and audit pricing in the United States. Journal of Accounting Research 52(2): 303-339.

Badolato, P. G., Donelson, D. C., Ege, M., 2014. Audit committee financial expertise and earnings management: The role of status. Journal of Accounting and Economics 58: 208-230.

Bell, T. B., Causholli, M., Knechel, W. R., 2015. Audit firm tenure, non audit services, and internal assessments of audit quality. Journal of Accounting Research 53(3): 461-509.

Bhandari, A., Mammadov, B., Shelton, A., Thevenot, M., 2018. It is not only what you know, it is also who you know: CEO network connections and financial reporting quality. Auditing: A Journal of Practice \& Theory 37(2): 27-50.

Billings, B. A., Gao, X., Jia, Y., 2014. CEO and CFO equity incentives and the pricing of audit services. Auditing: A Journal of Practice \& Theory. 33(2): 1-25.

Bills, K. L., Stephens, N. M., 2016. Spatial competition at the intersection of the large and small audit firm markets. Auditing: A Journal of Practice \& Theory. 35(1): 23-45.

Bills, K. L., Jeter, D. C., Stein, S. E., 2015. Auditor industry specialization and evidence of cost efficiencies in homogenous industries. The Accounting Review 90(5): 1721-1754.

Bills, K. L., Cunningham, L. M., Myers, L. A., 2016. Small audit firm membership in associations, networks, and alliances: Implications for audit quality and audit fees. The Accounting Review 91(3): 767-792.

Bradshaw, M. T., Richardson, S. A., Sloan, R. G., 2001. Do analysts and auditors use information in accruals? Journal of Accounting Research 39 (1):45-74.

Bruynseels, L., Cardinaels, E., 2014. The audit committee: Management watchdog or personal friend of the CEO? The Accounting Review 89(1): 113-145.

Cahan, S. F., Jeter, D. C., Naiker, V., 2011. Are all industry specialist auditors the same? Auditing: A Journal of Practice \& Theory. 30(4): 191-222. 
Chan, D., 1999. Low-balling and efficiency in a two-period specialization model of auditing competition. Contemporary Accounting Research 16 (4): 609-642.

Chan, L. H., Chen, K. C., Chen, T. Y., Yu, Y., 2012. The effects of firm-initiated clawback provisions on earnings quality and auditor behavior. Journal of Accounting and Economics 54(2): 180-196.

Chu, L., Simunic, D. A., Ye, M., Zhang, P., 2018. Transaction costs and competition among audit firms in local markets. Journal of Accounting and Economics 65: 129-147.

Cohen, J. R., U. Hoitash, G. Krishnamoorthy, Wright, A. M., 2014. The effect of audit committee industry expertise on monitoring the financial reporting process. The Accounting Review 89(1): 243-273.

de Villiers, C., Hay, D., Zhang, Z., 2014. Audit fee stickiness. Managerial Auditing Journal 29(1): $2-26$.

DeAngelo, L. E., 1981. Auditor independence, 'low balling', and disclosure regulation. Journal of Accounting and Economics 3: 113-127.

Dechow, P. M., Sloan, R. G., Sweeney, A. P., 1995. Detecting earnings management. The Accounting Review 70 (2): 193-225.

DeFond, M., Ettredge, M., Smith, D., 1997. An investigation of auditor resignations. Research in Accounting Regulation 11: 25-45.

DeFond, M., Lennox, C., 2011. The effect of SOX on small auditor exits and audit quality. Journal of Accounting and Economics 52 (1): 21-40.

Desir, R., Casterella, J., Kokina, J., 2014. A reexamination of audit fees for initial audit engagements in the post-SOX period. Auditing: A Journal of Practice and Theory 33 (2): 5978.

Donohoe, M. P., Knechel, W. R., 2014. Does corporate tax aggressiveness influence audit pricing? Contemporary Accounting Research 31(1): 284-308.

Doogar, R., Rowe, S. P., Sivadasan, P., 2015. Asleep at the wheel (again)? Bank audits during the lead up to the financial crisis. Contemporary Accounting Research 32(1): 358-391.

Doogar, R., P. Sivadasan, Solomon, I., 2015. Audit fee residuals: costs or rents? Review of Accounting Studies 20 (4):1247- 1286.

Doyle, J.T., W. Ge, and S. McVay. 2007. Accruals quality and internal control over financial reporting. The Accounting Review 82(4): 1141-1170.

Ettredge, M., Greenberg, R., 1990. Determinants of fee cutting on initial audit engagements. Journal 
of Accounting Research (Spring): 198-210.

European Commission, 2011. Summary of Responses. Green Paper - Audit Policy: Lessons from the Crisis. Brussels, Belgium: EC.

Ferguson, A., Lennox, C., Taylor, S., 2005. Audit fee rigidities in the presence of market frictions: Evidence and explanations. Working paper.

Francis, J., LaFond, R., Olsson, P., Schipper, K., 2005. The market pricing of accruals quality. Journal of Accounting and Economics 39 (2): 295-327.

Ghosh, A., Tang, C. Y., 2015. Assessing financial reporting quality of family firms: The auditors' perspective. Journal of Accounting and Economics 60(1): 95-116.

Greiner, A., Kohlbeck, M. J., Smith, T. J., 2017. The relationship between aggressive real earnings management and current and future audit fees. Auditing: A Journal of Practice \& Theory 36(1): 85-107.

Gul, F. A., Simon, F., Bikki, J., 2009. Earnings quality: Some evidence on the role of auditor tenure and auditors' industry expertise. Journal of Accounting and Economics 47 (3): 265-287.

Hay, D. C., Knechel, W. R., Wong, N., 2006. Audit fees: A meta-analysis of the effect of supply and demand attributes. Contemporary Accounting Research, 23(1): 141-191.

Healy, P., Wahlen, J., 1999. A review of the earnings management literature and its implications for standard setting. Accounting Horizons, 13(4), 365-383.

Hoag, M. L., Hollingsworth, C. W., 2011. An intertemporal analysis of audit fees and Section 404 material weaknesses. Auditing: A Journal of Practice \& Theory. 30(2): 173-200.

Huang, H. W., Raghunandan, K., Huang, T. C., Chiou, J. R., 2015. Fee discounting and audit quality following audit firm and audit partner changes: Chinese evidence. The Accounting Review 90 (4): 1517-1546.

Jha, A., Chen, Y., 2015. Audit fees and social capital. The Accounting Review 90(2): 611-639.

Keune, M. B., Mayhew, B.W., Schmidt, J. J., 2016. Non-Big 4 local market leadership and its effect on competition. The Accounting Review 91(3): 907-931.

Kim, Y., Li, H., Li, S., 2015. CEO equity incentives and audit fees. Contemporary Accounting Research. 32(2): 608-638.

Koh, K., Tong, Y. H. 2013. The effects of clients' controversial activities on audit pricing. Auditing: A Journal of Practice \& Theory. 32 (2): 67-96. 
Kothari, S. P., Leone, A. L., Wasley, C. E., 2005. Performance matched discretionary accrual measures. Journal of Accounting and Economics, 39 (1): 163-197.

Krishnan, G. V., Wang, C., 2015. The relation between managerial ability and audit fees and going concern opinions. Auditing: A Journal of Practice \& Theory. 34(3): 139-160.

Krishnan, J., Krishnan, J., 1997. Litigation risk and auditor resignations. The Accounting Review 72 (4): 539-560.

Lawson, B. P., Wang, D., 2016. The earnings quality information content of dividend policies and audit pricing. Contemporary Accounting Research. 33(4): 1685-1719.

Lobo, G.J., Zhao, Y., 2013. Relation between audit effort and financial report misstatements: Evidence from quarterly and annual restatements. The Accounting Review 88(4): 1385-1412.

Lu, L. Y., Wu, H., Yu, Y., 2017. Investment-related pressure and audit risk. Auditing: A Journal of Practice \& Theory 36(3): 137-157.

Markelevich, A., Rosner, R. L., 2013. Auditor fees and fraud firms. Contemporary Accounting Research. 30(4): 1590-1625.

Messier Jr., W. F., Reynolds, J. K., Simon, C. A., Wood, D. A., 2011. The effect of using the internal audit function as a management training ground on the external auditor's reliance decision. The Accounting Review 86(6): 2131-2154.

National Commission on Fraudulent Financial Reporting (NCFFR), 1987. Report of the National Commission on Fraudulent Financial Reporting. AICPA: New York, NY.

Ogneva, M., Subramanyam, K. R., Raghunandan, K., 2007. Internal control weakness and cost of equity: Evidence from SOX Section 404 disclosures. The Accounting Review. 82(5): 12551297.

Numan, W., Willekens, M., 2012. An empirical test of spatial competition in the audit market. Journal of Accounting and Economics 53(1): 450-465.

Ramos, M., 2012. How the clarified auditing standards will affect you. https://blog.aicpa.org/2012/12/how-the-clarified-auditing-standards-will-affectyou.html\#sthash.S17YKyb0.dpbs

Romanus, R. N., Maher, J. J., Fleming, D. M., 2008. Auditor industry specialization, auditor changes, and accounting restatements. Accounting Horizons 22: 389-413.

Securities and Exchange Commission, 2000. Financial Reporting Release No. 56: Revision of the commission's auditor independence requirements. Washington, DC: SEC. 
Securities and Exchange Commission, 2001. Office of the Chief Accountant: Application of Revised Ruleson Auditor Independence - Frequently Asked Questions. Washington, DC: SEC. www.sec.gov/info/accountants/audindep/audinfaq.htm

Securities and Exchange Commission, 2003a. Financial Reporting Release No. 68: Revision of the commission's auditor independence requirements. Washington, DC: SEC.

Securities and Exchange Commission, 2003b. Letter from Deputy SEC Chief Accountant to Ernst \& Young (July 8). Washington, DC: SEC.

Securities and Exchange Commission, 2007. Office of the Chief Accountant: Application of the Commission's Rules on Auditor Independence Frequently Asked Questions. Washington, DC: SEC. www.sec.gov/info/accountants/ocafaqaudind080607.

Simon, D. T., Francis, J. R., 1988. The effects of auditor change on audit fees: Tests of price cutting and price recovery. The Accounting Review (April): 255-269.

Stanley, J. D., 2011. Is the audit fee disclosure a leading indicator of clients' business risk? Auditing: A Journal of Practice \& Theory. 30(3): 157-179.

Turner, L. E., 2002a. Oversight Hearing on Accounting and Investor Protection Issues Raised by Enron and Other Public Companies. US Senate Committee on Banking, Housing and Urban Affairs (February 26).

Turner, L. E., 2002b. H.R. 3763 - The Corporate and Auditing Accountability, Responsibility, and Transparency Act of 2002. Hearings before the Committee on Financial Services. (March 13, 20, April 9, 2002).

U.S. House of Representatives, 1985. Hearings before the Subcommittee on Oversight and Investigations of the Committee on Energy and Commerce. No. 99-17. U.S. Government Printing Office: Washington, DC.

U.S. Senate, 1977. Improving the Accountability of Publicly Owned Corporations and Their Auditors. Prepared by the Subcommittee on Reports, Accounting and Management of the Committee on Governmental Affairs. U.S. Government Printing Office: Washington, DC.

U.S. Senate, 2002. Accounting reform and investor protection. Hearings before the Committee on Banking, Housing, and Urban Affairs. S.107-948. February 12, 14, 26 and 27. U.S. Government Printing Office: Washington, DC.

Wang, Y., Chui, A. C., 2015. Product market competition and audit fees. Auditing: A Journal of Practice \& Theory 34(4): 139-156.

Whisenant, S., Sankaraguruswamy, S., Raghunandan, K., 2003. Market reactions to disclosure of reportable events. Auditing: A Journal of Practice \& Theory 22(1): 181-194. 
Zhang, J. A., 2018. Accounting comparability, audit effort, and audit outcomes. Contemporary Accounting Research 35(1): 245-276.

Zmijewski, M., 1984. Methodological issues related to the estimation of financial distress prediction models. Journal of Accounting Research (Supplement): 59-82. 


\section{Appendix}

Variable Definitions

\begin{tabular}{|c|c|}
\hline AF1 & $\begin{array}{l}\text { Audit fees (in dollars). During the auditor change year, this variable captures the } \\
\text { fee paid to the successor auditor only. }\end{array}$ \\
\hline AF2 & $\begin{array}{l}\text { Audit fees (in dollars). During the auditor change year, this variable captures the } \\
\text { fee paid to the successor auditor if the company discloses only the fee paid to the } \\
\text { successor auditor, whereas it captures the fee to the predecessor auditor if the } \\
\text { company discloses both fees. }\end{array}$ \\
\hline AF3 & $\begin{array}{l}\text { Audit fees (in dollars). During the auditor change year, this variable captures the } \\
\text { fee paid to the successor auditor if the company discloses only the fee paid to the } \\
\text { successor auditor, whereas it captures the higher of the two fees if the company } \\
\text { discloses both fees. }\end{array}$ \\
\hline AF4 & $\begin{array}{l}\text { Audit fees (in dollars). During the auditor change year, this variable captures the } \\
\text { fee paid to the successor auditor if the company discloses only the fee paid to the } \\
\text { successor auditor, whereas it captures the combined fees if the company } \\
\text { discloses both fees. }\end{array}$ \\
\hline LAF1 & Natural logarithm of $A F 1$. \\
\hline LAF2 & Natural logarithm of $A F 2$. \\
\hline LAF3 & Natural logarithm of $A F 3$. \\
\hline LAF4 & Natural logarithm of AF4. \\
\hline INITIAL & Indicator that equals one in the auditor change year (zero otherwise). \\
\hline LDAYS & $\begin{array}{l}\text { The log of the number of days from the beginning of the fiscal year until the } \\
\text { appointment of the successor auditor (zero in observations where there is no } \\
\text { change of auditor). }\end{array}$ \\
\hline LAF1_Corr & 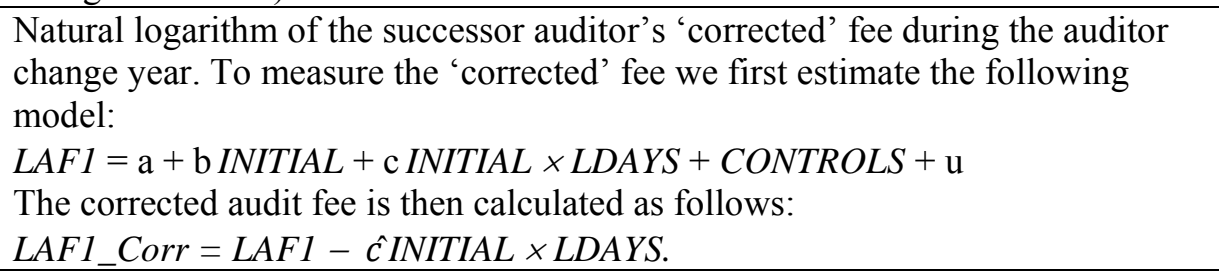 \\
\hline DISCOUNT & $\begin{array}{l}\text { Indicator that equals one if the successor auditor's 'corrected' audit fee } \\
\text { (LAF1_Corr) is less than the predicted 'corrected' fee using the residuals } \\
\text { estimated from Column (4) of Table } 6 \text { (zero otherwise). }\end{array}$ \\
\hline LTA & Natural logarithm of total assets (in millions of dollars). \\
\hline$L I Q$ & Current ratio (current assets divided by current liabilities). \\
\hline$R O A$ & Return on assets (net income divided by total assets). \\
\hline RECINV & Percentage of total assets in receivables and inventories. \\
\hline$L E V$ & Ratio of total liabilities to total assets. \\
\hline SQSEG & Square root of the number of business segments. \\
\hline FOREIGN & $\begin{array}{l}\text { Indicator that equals one if at least one foreign segment is reported in the } \\
\text { Compustat segments database (zero otherwise). }\end{array}$ \\
\hline EXORD & $\begin{array}{l}\text { Indicator that equals one if the company reports extraordinary items (zero } \\
\text { otherwise). }\end{array}$ \\
\hline RESTATE & $\begin{array}{l}\text { Indicator that equals one if the audited financial statements are subsequently } \\
\text { restated (zero otherwise). }\end{array}$ \\
\hline$G C$ & $\begin{array}{l}\text { Indicator that equals one if the audit report is modified for going concern issues } \\
\text { (zero otherwise). }\end{array}$ \\
\hline D_MW & $\begin{array}{l}\text { Indicator that equals one if there is a SOX 404(b) audit opinion on internal } \\
\text { controls (zero otherwise). }\end{array}$ \\
\hline
\end{tabular}




\begin{tabular}{|c|c|}
\hline$M W$ & $\begin{array}{l}\text { Indicator that equals one if the SOX 404(b) internal control opinion discloses a } \\
\text { material weakness (zero otherwise). }\end{array}$ \\
\hline BIG4 & Indicator that equals one if the auditor is one of the Big 4 firms (zero otherwise). \\
\hline LOSS & $\begin{array}{l}\text { Indicator that equals one if income from continuing operations is negative (zero } \\
\text { otherwise). }\end{array}$ \\
\hline REPLAG & $\begin{array}{l}\text { The square root of the number of days between the fiscal year-end and the audit } \\
\text { report date. }\end{array}$ \\
\hline EXTREME_SALES & $\begin{array}{l}\text { Indicator that equals one if the company's annual sales growth is in the highest } \\
\text { quintile of sales growth for the industry (zero otherwise). }\end{array}$ \\
\hline RZ_SCORE & $\begin{array}{l}\text { Decile rank of the company's estimated bankruptcy probability (which is } \\
\text { estimated following Zmijewski (1984)). }\end{array}$ \\
\hline RESTRUCTURE & $\begin{array}{l}\text { Indicator that equals one if the company reports restructuring charges (zero } \\
\text { otherwise). }\end{array}$ \\
\hline GROWTH & Sales growth, measured as the change in sales divided by lagged sales. \\
\hline FINANCE & $\begin{array}{l}\text { Indicator that equals one if outstanding shares or debt increase by ten percent or } \\
\text { more (zero otherwise). }\end{array}$ \\
\hline ATA & $\begin{array}{l}\text { Abnormal total accruals. We estimate abnormal total accruals using the } \\
\text { estimated residuals from the modified Jones model }(D e c h o w \text { et al. 1995): } \\
T A_{i t} / A_{i t-1}=\beta_{0}\left(1 / A_{i t-1}\right)+\beta_{1}\left(\Delta R E V_{i t} / A_{i t-1}\right)+\beta_{2}\left(\operatorname{PPE}_{i t} / A_{i t-1}\right)+\mathrm{e}_{i t} \\
\text { where: } \\
\text { total accruals }\left(T A_{i t}\right) \text { is measured as net income before extraordinary items minus } \\
\text { operating cash flows, } A_{i t-1} \text { is lagged total assets, } R E V_{i t} \text { is the annual change in } \\
\text { revenues, and PPE } E_{i t} \text { is gross plant property and equipment. We estimate the model } \\
\text { for each two-digit SIC industry-year with at least } 10 \text { observations using all } \\
\text { observations with the required data in Compustat. }\end{array}$ \\
\hline PMATA & $\begin{array}{l}\text { Performance-matched abnormal total accruals. We derive PMATA by adjusting } \\
\text { ATA for performance matching following the approach used in Francis et al. } \\
\text { (2005). Specifically, we form performance decile groups by industry-year based } \\
\text { on the current year's return on assets (ROA). PMATA is estimated as the } \\
\text { difference between ATA and median ATA for the ROA decile to which the } \\
\text { company belongs (where the median is calculated excluding the focal company). }\end{array}$ \\
\hline$\overline{A C A}$ & $\begin{array}{l}\text { Abnormal current accruals. We estimate abnormal current accruals using the } \\
\text { estimated residuals from the current accruals model of Ashbaugh et al. (1993). } \\
T C A_{i t} / A_{i t-1}=\beta_{0}\left(1 / A_{i t-1}\right)+\beta_{1}\left(\triangle R E V_{i t} / A_{i t-1}\right)+\mathrm{e}_{i t} \\
\text { where: } \\
\text { total current accruals }\left(T C A_{i t}\right) \text { is measured by adding depreciation and } \\
\text { amortization to total accruals, } A_{i t-1} \text { is lagged total assets, and } R E V_{i t} \text { is the annual } \\
\text { change in revenues. We estimate the model for each two-digit SIC industry-year } \\
\text { with at least } 10 \text { observations using all observations with the required data in } \\
\text { Compustat. }\end{array}$ \\
\hline PMACA & $\begin{array}{l}\text { Performance-matched abnormal current accruals. We derive PMACA by } \\
\text { adjusting ACA for performance matching following the approach used in Francis } \\
\text { et al. (2005). Specifically, we form performance decile groups by industry-year } \\
\text { based on the current year's return on assets (ROA). PMACA is estimated as the } \\
\text { difference between ACA and median ACA for the ROA decile to which the } \\
\text { company belongs (where the median is calculated excluding the focal company). }\end{array}$ \\
\hline
\end{tabular}


Table 1

Audit fee discounting results reported in prior studies (2011-2018).

\begin{tabular}{|c|c|c|c|c|c|}
\hline Study & $\begin{array}{l}\text { Sample } \\
\text { period }\end{array}$ & Sample Size & Variable Definition & Coefficient & $\begin{array}{l}\text { Significance } \\
t \text { or } p \text { value }\end{array}$ \\
\hline $\begin{array}{l}\text { Cahan et al. } \\
\text { (2011 AJPT) }\end{array}$ & $2003-2007$ & 9,565 & $\begin{array}{l}\text { INITIAL }=1 \text { if auditor tenure is no } \\
\text { more than two years, } 0 \text { otherwise. }\end{array}$ & -0.367 & $\mathrm{p}<0.001$ \\
\hline $\begin{array}{l}\text { Hoag and } \\
\text { Hollingsworth } \\
\text { (2011 AJPT) }\end{array}$ & $2004-2007$ & 13,788 & $\begin{array}{l}N E W=1 \text { in the auditor change year, } \\
0 \text { otherwise. }\end{array}$ & 0.040 & $\begin{array}{c}\text { Not } \\
\text { significant }\end{array}$ \\
\hline $\begin{array}{l}\text { Messier et al. } \\
\text { (2011 TAR) }\end{array}$ & $2000-2005$ & 33,928 & $\begin{array}{l}\text { AUDITORCHANGE }=1 \text { in the } \\
\text { auditor change year, } 0 \text { otherwise. }\end{array}$ & -0.197 & $\mathrm{t}=-14.21$ \\
\hline $\begin{array}{c}\text { Stanley } \\
\text { (2011 AJPT) }\end{array}$ & $2000-2007$ & 24,339 & $\begin{array}{l}\text { FIRSTYR }=1 \text { in the auditor change } \\
\text { year, } 0 \text { otherwise. }\end{array}$ & -0.13 & $t=-8.64$ \\
\hline $\begin{array}{l}\text { Chan et al. } \\
\text { (2012 JAE) }\end{array}$ & $2000-2009$ & 15,157 & $\begin{array}{l}\text { AUDITORCHANGE }=1 \text { in the } \\
\text { auditor change year, } 0 \text { otherwise. }\end{array}$ & -0.084 & $\mathrm{t}=-3.86$ \\
\hline $\begin{array}{l}\text { Numan and } \\
\text { Willekens } \\
\text { (2012 JAE) }\end{array}$ & $2005-2006$ & 2,637 & $\begin{array}{l}\text { SWITCH }=1 \text { in the auditor change } \\
\text { year, } 0 \text { otherwise. }\end{array}$ & -0.548 & $t=-4.77$ \\
\hline $\begin{array}{l}\text { Koh and Tong } \\
\text { (2013 AJPT) }\end{array}$ & $2000-2010$ & 20,687 & $\begin{array}{l}\text { DNewClient }=1 \text { in the auditor } \\
\text { change year, } 0 \text { otherwise. }\end{array}$ & -0.148 & $\mathrm{t}=-5.92$ \\
\hline $\begin{array}{l}\text { Lobo and Zhao } \\
\text { (2013 TAR) }\end{array}$ & $2000-2009$ & 32,915 & $\begin{array}{l}\text { SHORT_TENURE }=1 \text { if auditor } \\
\text { tenure is no more than three years, } 0 \\
\text { otherwise. }\end{array}$ & -0.036 & $\mathrm{p}=0.002$ \\
\hline $\begin{array}{l}\text { Markelevich } \\
\text { and Rosner } \\
(2013 \mathrm{CAR})\end{array}$ & $2000-2010$ & 11,830 & $\begin{array}{l}\text { SWITCH }=1 \text { in the auditor change } \\
\text { year, } 0 \text { otherwise. }\end{array}$ & -0.036 & $\mathrm{t}=-1.84$ \\
\hline $\begin{array}{l}\text { Badertscher et } \\
\text { al. (2014 JAR) }\end{array}$ & $2000-2009$ & 5,820 & $\begin{array}{l}A U D \_T O=1 \text { in the auditor change } \\
\text { year, } 0 \text { otherwise. }\end{array}$ & -0.280 & $t=-5.642$ \\
\hline $\begin{array}{l}\text { Billings et al. } \\
\text { (2014 AJPT) }\end{array}$ & $2000-2009$ & 5,004 & $\begin{array}{l}\text { INITIAL }=1 \text { if auditor tenure is no } \\
\text { more than two years, } 0 \text { otherwise. }\end{array}$ & -0.053 & $\mathrm{t}=-2.03$ \\
\hline $\begin{array}{l}\text { Bruynseels and } \\
\text { Cardinaels } \\
(2014 \text { TAR })\end{array}$ & $2004-2008$ & 11,004 & $\begin{array}{l}\text { INITIAL }=1 \text { in the auditor change } \\
\text { year, } 0 \text { otherwise. }\end{array}$ & -0.034 & $\mathrm{t}=-1.22$ \\
\hline $\begin{array}{l}\text { Cohen et al. } \\
\text { (2014 TAR) }\end{array}$ & $2001-2007$ & 18,564 & $\begin{array}{l}\text { AUDITOR_CHANGE }=1 \text { in the } \\
\text { auditor change year, } 0 \text { otherwise. }\end{array}$ & -0.121 & $\mathrm{t}=-1.17$ \\
\hline $\begin{array}{l}\text { Desir et al. } \\
(2014 \text { AJPT) }\end{array}$ & $2006-2010$ & $\begin{array}{c}\text { varies across } \\
\text { years }\end{array}$ & $\begin{array}{l}\text { INITIAL }=1 \text { in the auditor change } \\
\text { year, } 0 \text { otherwise. }\end{array}$ & $\begin{array}{l}\text { negative in } \\
\text { each year }\end{array}$ & $\begin{array}{l}\text { significant } \\
\text { in } 2007- \\
2010, \text { but } \\
\text { not in } 2006\end{array}$ \\
\hline $\begin{array}{l}\text { Donohoe and } \\
\text { Knechel } \\
\text { (2014 CAR) }\end{array}$ & $2002-2010$ & 32,315 & $\begin{array}{l}\text { TENURE = } 1 \text { if auditor tenure is no } \\
\text { more than two years, } 0 \text { otherwise. }\end{array}$ & -0.106 & $\mathrm{p}<0.001$ \\
\hline $\begin{array}{l}\text { Bell et al. } \\
\text { (2015 JAR) }\end{array}$ & 2003 & 265 & $\begin{array}{l}F I R S T=1 \text { in the auditor change } \\
\text { year, } 0 \text { otherwise. }\end{array}$ & -0.112 & $t=-2.66$ \\
\hline $\begin{array}{l}\text { Bills et al. } \\
\text { (2015 TAR) }\end{array}$ & $2004-2009$ & 23,578 & $\begin{array}{l}\text { FIRSTYR }=1 \text { in the auditor change } \\
\text { year, } 0 \text { otherwise. }\end{array}$ & -0.095 & $t=-5.96$ \\
\hline $\begin{array}{l}\text { Doogar et al. } \\
(2015 \text { CAR) }\end{array}$ & $2005-2007$ & $\begin{array}{c}283 \text { in each } \\
\text { year }\end{array}$ & $\begin{array}{l}\text { AUD_CHG }=1 \text { in the auditor } \\
\text { change year, } 0 \text { otherwise. }\end{array}$ & $\begin{array}{r}0.033 \\
-0.003 \\
-0.268 \\
\end{array}$ & $\begin{array}{l}t=0.31 \\
t=-0.04 \\
t=-1.76\end{array}$ \\
\hline $\begin{array}{l}\text { Ghosh and Tang } \\
\text { (2015 JAE) }\end{array}$ & $2003-2010$ & 9,191 & $\begin{array}{l}\text { AUDITOR-CHANGE }=1 \text { in the } \\
\text { auditor change year, } 0 \text { otherwise. }\end{array}$ & -0.0357 & $\mathrm{t}=-0.91$ \\
\hline $\begin{array}{l}\text { Jha and Chen } \\
\text { (2015 TAR) }\end{array}$ & $2000-2009$ & 28,634 & $\begin{array}{l}\text { AUDITOR CHANGE }=1 \text { in the } \\
\text { auditor change year, } 0 \text { otherwise. }\end{array}$ & -0.094 & $\mathrm{p}<0.001$ \\
\hline
\end{tabular}




\begin{tabular}{|c|c|c|c|c|c|}
\hline $\begin{array}{l}\text { Kim et al. } \\
\text { (2015 CAR) }\end{array}$ & $2000-2009$ & 11,726 & $\begin{array}{l}\text { AUDITOR_CHANGE }=1 \text { in the } \\
\text { auditor change year, } 0 \text { otherwise. }\end{array}$ & 0.053 & $\mathrm{t}=2.141$ \\
\hline $\begin{array}{l}\text { Krishnan and } \\
\text { Wang } \\
\text { (2015 AJPT) }\end{array}$ & $2000-2011$ & 30,986 & $\begin{array}{l}\text { INITIAL }=1 \text { in the auditor change } \\
\text { year, } 0 \text { otherwise. }\end{array}$ & -0.066 & $\mathrm{p}=0.031$ \\
\hline $\begin{array}{l}\text { Wang and Chui } \\
\text { (2015 AJPT) }\end{array}$ & $2000-2009$ & 4,615 & $\begin{array}{l}\text { SWITCH }=1 \text { in the auditor change } \\
\text { year, } 0 \text { otherwise. }\end{array}$ & -0.107 & $\mathrm{t}=-1.93$ \\
\hline $\begin{array}{l}\text { Doogar et al. } \\
\text { (2015 RAST) }\end{array}$ & $2003-2010$ & 19,440 & $\begin{array}{l}N E W=1 \text { in the auditor change year, } \\
0 \text { otherwise. }\end{array}$ & -0.151 & $\mathrm{t}=-3.90$ \\
\hline $\begin{array}{l}\text { Bills et al. } \\
\text { (2016 TAR) }\end{array}$ & $2010-2013$ & 2,776 & $\begin{array}{l}\text { SHORT_TENURE }=1 \text { if auditor } \\
\text { tenure is no more than three years, } 0 \\
\text { otherwise. }\end{array}$ & -0.040 & $\mathrm{p}=0.035$ \\
\hline $\begin{array}{c}\text { Bills and } \\
\text { Stephens } \\
\text { (2016 AJPT) }\end{array}$ & $2004-2013$ & 16,073 & $\begin{array}{l}\text { FIRSTYR }=1 \text { in the auditor change } \\
\text { year, } 0 \text { otherwise. }\end{array}$ & -0.089 & $\mathrm{t}=-3.94$ \\
\hline $\begin{array}{l}\text { Keune et al. } \\
\text { (2016 TAR) }\end{array}$ & $2005-2010$ & 17,474 & $\begin{array}{l}A C H G=1 \text { in the auditor change } \\
\text { year, } 0 \text { otherwise. }\end{array}$ & -0.14 & $\mathrm{t}=-7.38$ \\
\hline $\begin{array}{l}\text { Lawson and } \\
\text { Wang } \\
\text { (2016 CAR) }\end{array}$ & 2004-2012 & 19,351 & $\begin{array}{l}C H G \_Y E A R=1 \text { in the auditor } \\
\text { change year, } 0 \text { otherwise. }\end{array}$ & -0.118 & $\mathrm{t}=-3.279$ \\
\hline $\begin{array}{c}\text { Lu et al. } \\
(2017 \text { AJPT) }\end{array}$ & $2000-2012$ & 2,062 & $\begin{array}{l}\text { AuditorChange }=1 \text { in the auditor } \\
\text { change year, } 0 \text { otherwise. }\end{array}$ & -0.074 & $\mathrm{t}=-2.83$ \\
\hline $\begin{array}{l}\text { Greiner et al. } \\
\text { (2017 AJPT) }\end{array}$ & $2005-2011$ & 21,907 & $\begin{array}{l}\text { CHANGE }=1 \text { in the auditor change } \\
\text { year, } 0 \text { otherwise. }\end{array}$ & -0.026 & $\mathrm{t}=-5.53$ \\
\hline $\begin{array}{l}\text { Chu et al. } \\
\text { (2018 JAE) }\end{array}$ & $2005-2006$ & 2,602 & $\begin{array}{l}\text { SWITCH }=1 \text { in the auditor change } \\
\text { year, } 0 \text { otherwise. }\end{array}$ & -0.301 & $\mathrm{t}=-3.68$ \\
\hline $\begin{array}{l}\text { Bhandari et al. } \\
\text { (2018 AJPT) }\end{array}$ & 2002-2014 & 5,611 & $\begin{array}{l}\text { INITIAL }=1 \text { in the auditor change } \\
\text { year, } 0 \text { otherwise. }\end{array}$ & -0.123 & $\mathrm{t}=-2.86$ \\
\hline $\begin{array}{l}\text { Albrecht et al } \\
\text { (2018 TAR) }\end{array}$ & 2004-2013 & 19,058 & $\begin{array}{l}\text { SHORT_TENURE }=1 \text { if auditor } \\
\text { tenure is no more than two years, } 0 \\
\text { otherwise. }\end{array}$ & -0.178 & $\mathrm{t}=-2.29$ \\
\hline $\begin{array}{c}\text { Zhang } \\
\text { (2018 CAR) }\end{array}$ & $2000-2011$ & 21,152 & $\begin{array}{l}\text { AudChg }=1 \text { in the auditor change } \\
\text { year, } 0 \text { otherwise. }\end{array}$ & -0.095 & $\mathrm{t}=-5.23$ \\
\hline
\end{tabular}

Note: Table 1 presents the results for initial fee discounting in articles published in the years 2011-2018 in six accounting journals (The Accounting Review (TAR); Auditing: A Journal of Practice \& Theory (AJPT); Contemporary Accounting Research (CAR); Journal of Accounting and Economics (JAE); Journal of Accounting Research (JAR); and Review of Accounting Studies (RAST)). We only include studies examining U.S. companies. 
Table 2

Sample derivation.

Initial sample after merging the Audit Analytics data on audit fees, audit

Number of observations

opinions, and auditor changes with observations in the Compustat

database (2004-2015).

Less:

Foreign companies

Financial companies (4-digit SIC codes 6000-6999)

Missing total asset variable or total assets $<\$ 1$ million

Missing other control variables

Final Sample

46,970

This table details the sample selection process. To identify auditor change observations, we impose the following conditions: (a) the new auditor is appointed at some point between the beginning of the fiscal year and within 60 days of the fiscal year-end and (b) the new auditor signs the audit opinion for the year-end financial statements. The final sample includes 3,102 auditor change observations. 


\section{Table 3}

Sample distribution.

Panel A: Frequency of initial-year audits and types of audit fee disclosures

\begin{tabular}{c|cccccc}
\hline Fiscal year & $\begin{array}{c}\text { All } \\
\text { Observations }\end{array}$ & $\begin{array}{c}\text { Auditor } \\
\text { changes }\end{array}$ & $\begin{array}{c}\text { The auditor change } \\
\text { company discloses } \\
\text { only the fee paid to } \\
\text { the successor auditor }\end{array}$ & $\begin{array}{c}\text { The auditor change } \\
\text { company discloses the } \\
\text { fees paid to the successor } \\
\text { and predecessor auditors }\end{array}$ \\
\hline 2004 & 4,683 & 417 & 232 & $56 \%$ & 185 & $44 \%$ \\
2005 & 4,499 & 434 & 267 & $62 \%$ & 167 & $38 \%$ \\
2006 & 4,367 & 361 & 227 & $63 \%$ & 134 & $37 \%$ \\
2007 & 4,124 & 281 & 179 & $64 \%$ & 102 & $36 \%$ \\
2008 & 3,907 & 225 & 135 & $60 \%$ & 90 & $40 \%$ \\
2009 & 3,749 & 222 & 145 & $65 \%$ & 77 & $35 \%$ \\
2010 & 3,632 & 200 & 126 & $63 \%$ & 74 & $37 \%$ \\
2011 & 3,560 & 148 & 107 & $72 \%$ & 41 & $28 \%$ \\
2012 & 3,566 & 153 & 95 & $62 \%$ & 58 & $38 \%$ \\
2013 & 3,646 & 214 & 123 & $57 \%$ & 91 & $43 \%$ \\
2014 & 3,687 & 247 & 157 & $64 \%$ & 90 & $36 \%$ \\
2015 & 3,550 & 200 & 130 & $65 \%$ & 70 & $35 \%$ \\
Total & 46,970 & 3,102 & 1,923 & $62 \%$ & 1,179 & $38 \%$ \\
\hline
\end{tabular}

Panel A reports the number of initial-year audit engagements as well as the number and proportion in which companies disclose the fees paid to successor auditors only, or they disclose the fees paid to both the predecessor and successor auditors. 
Table 3 (cont.)

Sample distribution.

Panel B: Timing of successor auditor's appointment and the disclosure of audit fees

\begin{tabular}{lcccccc}
\hline & \multicolumn{6}{c}{ Successor auditor appointed: } \\
\cline { 2 - 5 } & $\begin{array}{c}\text { Fuarter } \\
(1)\end{array}$ & $\begin{array}{c}\text { Second } \\
\text { Quarter } \\
(2)\end{array}$ & $\begin{array}{c}\text { Third } \\
\text { Quarter } \\
(3)\end{array}$ & $\begin{array}{c}\text { Fourth } \\
\text { Quarter } \\
(4)\end{array}$ & $\begin{array}{c}\text { After the } \\
\text { year-end } \\
(5)\end{array}$ & $\begin{array}{c}\text { Total } \\
(6)\end{array}$ \\
\hline $\begin{array}{l}\text { The company discloses } \\
\text { only the fee paid to the }\end{array}$ & 326 & 683 & 416 & 348 & 150 & 1,923 \\
$\begin{array}{l}\text { successor auditor } \\
\begin{array}{l}\text { The company discloses } \\
\text { the fees paid to the }\end{array}\end{array}$ & $(83 \%)$ & $(66 \%)$ & $(52 \%)$ & $(55 \%)$ & $(60 \%)$ & $(62 \%)$ \\
$\begin{array}{l}\text { successor and } \\
\text { predecessor auditors }\end{array}$ & $(17 \%)$ & $(34 \%)$ & $(48 \%)$ & $(45 \%)$ & $(40 \%)$ & $(38 \%)$ \\
\hline
\end{tabular}

Panel B reports the timing of the successor auditor's appointment and the company's disclosure of audit fees paid to the successor auditor and predecessor auditor during the auditor change year.

Panel C: Timing of successor auditor's appointment and the proportion of fees paid to the successor auditor (sample is restricted to 1,179 companies which disclose the fees paid to both the successor and predecessor auditors)

\begin{tabular}{ccccccc}
\hline & \multicolumn{7}{c}{ Successor Auditor Appointed: } & \\
\cline { 2 - 6 } Proportion of Total & First & Second & Third & Fourth & After the & \\
Audit Fees Paid to & Quarter & $\begin{array}{c}\text { Quarter } \\
\text { Quarter }\end{array}$ & $\begin{array}{c}\text { Quarter } \\
\text { year-end }\end{array}$ & $\begin{array}{c}\text { Total } \\
(6)\end{array}$ \\
\hline Successor Auditor & $(1)$ & $(2)$ & $(3)$ & $(4)$ & $(5)$ & $(6)$ \\
\hline N & 67 & 347 & 379 & 286 & 100 & 1,179 \\
Mean & $78 \%$ & $77 \%$ & $68 \%$ & $59 \%$ & $60 \%$ & $69 \%$ \\
Median & $83 \%$ & $83 \%$ & $75 \%$ & $63 \%$ & $62 \%$ & $74 \%$ \\
\hline
\end{tabular}

Panel $\mathrm{C}$ reports the proportion of annual audit fees that is paid to the successor auditor by companies that disclose the fees paid to both the predecessor and successor auditors. 
Table 4

Descriptive statistics.

\begin{tabular}{lcccccc}
\hline & \multicolumn{2}{c}{$\begin{array}{c}\text { No auditor change } \\
\text { observations } \\
(n=43,868)\end{array}$} & \multicolumn{2}{c}{$\begin{array}{c}\text { Auditor change } \\
\text { observations } \\
(n=3,102)\end{array}$} & $\begin{array}{c}\text { Tests of differences } \\
\text { Auditor change vs. no } \\
\text { change observations }\end{array}$ \\
\hline Variables & Mean & Median & Mean & Median & $\begin{array}{c}\text { Mean test } \\
\text { (t-stat) }\end{array}$ & $\begin{array}{c}\text { Median test } \\
\text { (z-stat) }\end{array}$ \\
AF1 & $1,777,583$ & 800,000 & 643,927 & 243,039 & 37.84 & -31.78 \\
AF2 & $1,777,583$ & 800,000 & 498,280 & 162,136 & 47.19 & -38.57 \\
AF3 & $1,777,583$ & 800,000 & 656,411 & 257,821 & 37.35 & -31.18 \\
AF4 & $1,777,583$ & 800,000 & 727,398 & 286,598 & 32.44 & -28.98 \\
LAF1 & 13.476 & 13.592 & 12.423 & 12.401 & 40.58 & -31.78 \\
LAF2 & 13.476 & 13.592 & 12.044 & 11.996 & 55.00 & -38.57 \\
LAF3 & 13.476 & 13.592 & 12.488 & 12.460 & 38.16 & -31.18 \\
LAF4 & 13.476 & 13.592 & 12.601 & 12.566 & 33.80 & -28.98 \\
LTA & 5.790 & 5.876 & 4.163 & 4.043 & 41.21 & -31.40 \\
RECINV & 0.235 & 0.193 & 0.256 & 0.207 & -5.06 & 2.53 \\
LIQ & 2.824 & 1.880 & 2.968 & 1.755 & -2.05 & -3.49 \\
ROA & -0.114 & 0.025 & -0.313 & -0.042 & 15.24 & -19.84 \\
LEV & 0.590 & 0.514 & 0.649 & 0.501 & -5.02 & -1.67 \\
SQSEG & 1.306 & 1.000 & 1.243 & 1.000 & 6.24 & -5.68 \\
FOREIGN & 0.441 & & 0.348 & & 10.17 & \\
EXORD & 0.012 & & 0.009 & & 1.64 & \\
GC & 0.081 & & 0.207 & & -16.96 & \\
D & 0.624 & & 0.367 & & 28.62 & \\
MW & 0.037 & & 0.076 & & -7.98 & \\
BIG4 & 0.691 & & 0.425 & & 29.05 & \\
\hline & & & & & & \\
\hline
\end{tabular}

See the Appendix for variable definitions. 
Table 5

Replicating the approaches taken in prior studies.

Panel A: Including company fixed effects

\begin{tabular}{|c|c|c|c|c|}
\hline & $\begin{array}{l}\text { Successor fee } \\
\text { only. } \\
\text { LAF1 } \\
\text { (1) }\end{array}$ & $\begin{array}{l}\text { Predecessor fee if } \\
\text { available; successor } \\
\text { fee otherwise. } \\
\text { LAF2 } \\
\text { (2) }\end{array}$ & $\begin{array}{l}\text { Higher of successor } \\
\text { fee and predecessor } \\
\text { fee if available; } \\
\text { successor fee } \\
\text { otherwise. } \\
\text { LAF3 } \\
\text { (3) }\end{array}$ & $\begin{array}{l}\text { Sum of successor } \\
\text { fee and predecessor } \\
\text { fee if available; } \\
\text { successor fee } \\
\text { otherwise. } \\
\text { LAF4 } \\
\text { (4) }\end{array}$ \\
\hline INITIAL & $\begin{array}{c}-0.1939 * * * \\
{[-18.73]}\end{array}$ & $\begin{array}{c}-0.5849 * * * \\
{[-30.73]}\end{array}$ & $\begin{array}{c}-0.1329 * * * \\
{[-14.81]}\end{array}$ & $\begin{array}{c}-0.0224 * * \\
{[-2.51]}\end{array}$ \\
\hline LTA & $\begin{array}{c}0.3447 * * * \\
{[42.33]}\end{array}$ & $\begin{array}{c}0.3450 * * * \\
{[41.00]}\end{array}$ & $\begin{array}{c}0.3425 * * * \\
{[42.94]}\end{array}$ & $\begin{array}{c}0.3408 * * * \\
{[42.72]}\end{array}$ \\
\hline$L I Q$ & $\begin{array}{c}-0.0119 * * * \\
{[-8.34]}\end{array}$ & $\begin{array}{c}-0.0121 * * * \\
{[-7.79]}\end{array}$ & $\begin{array}{c}-0.0117 * * * \\
{[-8.24]}\end{array}$ & $\begin{array}{c}-0.0117 * * * \\
{[-8.28]}\end{array}$ \\
\hline$R O A$ & $\begin{array}{c}-0.0776 * * * \\
{[-6.21]}\end{array}$ & $\begin{array}{c}-0.0745^{* * *} \\
{[-5.52]}\end{array}$ & $\begin{array}{c}-0.0757 * * * \\
{[-6.13]}\end{array}$ & $\begin{array}{c}-0.0773 * * * \\
{[-6.22]}\end{array}$ \\
\hline$L E V$ & $\begin{array}{c}0.0662 * * * \\
{[5.65]}\end{array}$ & $\begin{array}{c}0.0730 * * * \\
{[5.93]}\end{array}$ & $\begin{array}{c}0.0690 * * * \\
{[6.02]}\end{array}$ & $\begin{array}{c}0.0673 * * * \\
{[5.91]}\end{array}$ \\
\hline RECINV & $\begin{array}{c}0.2908 * * * \\
{[6.56]}\end{array}$ & $\begin{array}{c}0.2387 * * * \\
{[5.33]}\end{array}$ & $\begin{array}{c}0.2857 * * * \\
{[6.67]}\end{array}$ & $\begin{array}{c}0.2870^{* * * *} \\
{[6.69]}\end{array}$ \\
\hline FOREIGN & $\begin{array}{c}0.0391 * * * \\
{[3.79]}\end{array}$ & $\begin{array}{c}0.0391 * * * \\
{[3.44]}\end{array}$ & $\begin{array}{c}0.0384 * * * \\
{[3.77]}\end{array}$ & $\begin{array}{c}0.0404 * * * \\
{[3.98]}\end{array}$ \\
\hline EXORD & $\begin{array}{c}0.0625 * * * \\
{[3.03]}\end{array}$ & $\begin{array}{c}0.0671 * * * \\
{[3.14]}\end{array}$ & $\begin{array}{c}0.0640 * * * \\
{[3.15]}\end{array}$ & $\begin{array}{c}0.0619 * * * \\
{[3.04]}\end{array}$ \\
\hline SQSEG & $\begin{array}{c}0.0244 * * * \\
{[2.80]}\end{array}$ & $\begin{array}{c}0.0234 * * \\
{[2.49]}\end{array}$ & $\begin{array}{c}0.0268 * * * \\
{[3.08]}\end{array}$ & $\begin{array}{c}0.0280 * * * \\
{[3.23]}\end{array}$ \\
\hline BIG4 & $\begin{array}{c}0.2661 * * * \\
{[15.66]}\end{array}$ & $\begin{array}{c}0.1203 * * * \\
{[5.58]}\end{array}$ & $\begin{array}{c}0.2928 * * * \\
{[17.45]}\end{array}$ & $\begin{array}{c}0.3323 * * * \\
{[19.90]}\end{array}$ \\
\hline$G C$ & $\begin{array}{c}0.0731 * * * \\
{[4.97]}\end{array}$ & $\begin{array}{c}0.0832 * * * \\
{[5.04]}\end{array}$ & $\begin{array}{c}0.0697 * * * \\
{[4.80]}\end{array}$ & $\begin{array}{c}0.0686^{* * * *} \\
{[4.72]}\end{array}$ \\
\hline$M W$ & $\begin{array}{c}0.2838 * * * \\
{[20.37]}\end{array}$ & $\begin{array}{c}0.2667 * * * \\
{[15.83]}\end{array}$ & $\begin{array}{c}0.2843 * * * \\
{[20.86]}\end{array}$ & $\begin{array}{c}0.2839 * * * \\
{[21.03]}\end{array}$ \\
\hline$D \_M W$ & $\begin{array}{c}0.2607 * * * \\
{[26.98]}\end{array}$ & $\begin{array}{c}0.2511 * * * \\
{[23.51]}\end{array}$ & $\begin{array}{c}0.2582 * * * \\
{[27.17]}\end{array}$ & $\begin{array}{c}0.2565 * * * \\
{[27.04]}\end{array}$ \\
\hline Year Fixed Effects & Yes & Yes & Yes & Yes \\
\hline Company Fixed Effects & Yes & Yes & Yes & Yes \\
\hline Observations & 46,970 & 46,970 & 46,970 & 46,970 \\
\hline Adjusted $R^{2}$ & $81 \%$ & $81 \%$ & $81 \%$ & $81 \%$ \\
\hline
\end{tabular}


Table 5 (cont.)

Replicating the approaches taken in prior studies.

Panel B: Not including company fixed effects

\begin{tabular}{|c|c|c|c|c|}
\hline & $\begin{array}{c}\text { Successor fee } \\
\text { only. } \\
\text { LAF1 } \\
(1)\end{array}$ & $\begin{array}{l}\text { Predecessor fee if } \\
\text { available; } \\
\text { successor fee } \\
\text { otherwise. } \\
L A F 2 \\
(2) \\
\end{array}$ & $\begin{array}{l}\text { Higher of successor } \\
\text { fee and predecessor } \\
\text { fee if available; } \\
\text { successor fee } \\
\text { otherwise. } \\
\text { LAF3 } \\
\text { (3) }\end{array}$ & $\begin{array}{l}\text { Sum of successor } \\
\text { fee and predecessor } \\
\text { fee if available; } \\
\text { successor fee } \\
\text { otherwise. } \\
\text { LAF4 } \\
(4)\end{array}$ \\
\hline INITIAL & $\begin{array}{c}-0.2067 * * * \\
{[-15.32]}\end{array}$ & $\begin{array}{c}-0.5942 * * * \\
{[-29.35]}\end{array}$ & $\begin{array}{c}-0.1425 * * * \\
{[-11.57]}\end{array}$ & $\begin{array}{c}-0.0293 * * \\
{[-2.39]}\end{array}$ \\
\hline LTA & $\begin{array}{c}0.4230^{* * *} \\
{[87.35]}\end{array}$ & $\begin{array}{c}0.4265^{* * *} \\
{[87.56]}\end{array}$ & $\begin{array}{c}0.4220^{* * *} \\
{[87.14]}\end{array}$ & $\begin{array}{c}0.4208 * * * \\
{[86.73]}\end{array}$ \\
\hline$L I Q$ & $\begin{array}{c}-0.0099 * * * \\
{[-5.07]}\end{array}$ & $\begin{array}{c}-0.0098 * * * \\
{[-4.98]}\end{array}$ & $\begin{array}{c}-0.0099 * * * \\
{[-5.12]}\end{array}$ & $\begin{array}{c}-0.0100 * * * \\
{[-5.17]}\end{array}$ \\
\hline$R O A$ & $\begin{array}{c}-0.1936^{* * *} \\
{[-12.89]}\end{array}$ & $\begin{array}{c}-0.1995 * * * \\
{[-12.98]}\end{array}$ & $\begin{array}{c}-0.1928 * * * \\
{[-12.82]}\end{array}$ & $\begin{array}{c}-0.1932 * * * \\
{[-12.79]}\end{array}$ \\
\hline$L E V$ & $\begin{array}{c}0.0919^{* * * *} \\
{[6.72]}\end{array}$ & $\begin{array}{c}0.0979 * * * \\
{[7.04]}\end{array}$ & $\begin{array}{c}0.0929 * * * \\
{[6.81]}\end{array}$ & $\begin{array}{c}0.0911 * * * \\
{[6.68]}\end{array}$ \\
\hline RECINV & $\begin{array}{c}0.4701 * * * \\
{[12.91]}\end{array}$ & $\begin{array}{c}0.4556 * * * \\
{[12.54]}\end{array}$ & $\begin{array}{c}0.4698 * * * \\
{[12.95]}\end{array}$ & $\begin{array}{c}0.4693 * * * \\
{[12.93]}\end{array}$ \\
\hline FOREIGN & $\begin{array}{c}0.3361 * * * \\
{[23.69]}\end{array}$ & $\begin{array}{c}0.3306^{* * *} \\
{[23.21]}\end{array}$ & $\begin{array}{c}0.3350 * * * \\
{[23.66]}\end{array}$ & $\begin{array}{c}0.3363 * * * \\
{[23.74]}\end{array}$ \\
\hline EXORD & $\begin{array}{c}0.0842 * * \\
{[2.42]}\end{array}$ & $\begin{array}{c}0.0938^{* * *} \\
{[2.65]}\end{array}$ & $\begin{array}{c}0.0858^{* *} \\
{[2.48]}\end{array}$ & $\begin{array}{c}0.0839^{* *} \\
{[2.42]}\end{array}$ \\
\hline SQSEG & $\begin{array}{c}0.0787 * * * \\
{[7.09]}\end{array}$ & $\begin{array}{c}0.0767 * * * \\
{[6.90]}\end{array}$ & $\begin{array}{c}0.0797 * * * \\
{[7.18]}\end{array}$ & $\begin{array}{c}0.0802 * * * \\
{[7.21]}\end{array}$ \\
\hline BIG4 & $\begin{array}{c}0.4581 * * * \\
{[26.93]}\end{array}$ & $\begin{array}{c}0.4196^{* * * *} \\
{[24.12]}\end{array}$ & $\begin{array}{c}0.4642 * * * \\
{[27.35]}\end{array}$ & $\begin{array}{c}0.4747 * * * \\
{[28.02]}\end{array}$ \\
\hline$G C$ & $\begin{array}{c}-0.0060 \\
{[-0.29]}\end{array}$ & $\begin{array}{l}0.0181 \\
{[0.87]}\end{array}$ & $\begin{array}{l}0.0003 \\
{[0.01]}\end{array}$ & $\begin{array}{l}-0.0011 \\
{[-0.05]}\end{array}$ \\
\hline$M W$ & $\begin{array}{c}0.4794 * * * \\
{[22.79]}\end{array}$ & $\begin{array}{c}0.4501 * * * \\
{[19.68]}\end{array}$ & $\begin{array}{c}0.4805^{* * *} \\
{[23.05]}\end{array}$ & $\begin{array}{c}0.4818 * * * \\
{[23.26]}\end{array}$ \\
\hline$D \_M W$ & $\begin{array}{c}0.3163^{* * * *} \\
{[20.86]}\end{array}$ & $\begin{array}{c}0.3127 * * * \\
{[20.38]}\end{array}$ & $\begin{array}{c}0.3138^{* * * *} \\
{[20.72]}\end{array}$ & $\begin{array}{c}0.3106^{* * * *} \\
{[20.51]}\end{array}$ \\
\hline Year Fixed Effects & Yes & Yes & Yes & Yes \\
\hline Company Fixed Effects & No & No & No & No \\
\hline Observations & 46,970 & 46,970 & 46,970 & 46,970 \\
\hline Adjusted $R^{2}$ & $82 \%$ & $81 \%$ & $82 \%$ & $82 \%$ \\
\hline
\end{tabular}

***, $* *$, and $*$ represent $\mathrm{p}<.01, .05$, and .1 , respectively; t-stats are in brackets.

Table 5 presents the results from audit fee regressions, in which audit fees during the auditor change year are defined in four different ways based on the approaches taken in prior studies. Column (1) uses only the fees paid to the successor auditor. Column (2) uses the fee paid to the predecessor auditor (if available) or the fee paid to the successor auditor otherwise. Column (3) uses the higher of the fee paid to the successor and predecessor auditors (if available) or the fee paid to the successor auditor otherwise. Column (4) uses the sum of the fees paid to the successor and predecessor auditors (if available) or the fee paid to the successor auditor otherwise. See the Appendix for variable definitions. 
Table 6

Are audit fees discounted?

\begin{tabular}{|c|c|c|c|c|}
\hline & $\begin{array}{l}\text { Sample excludes companies } \\
\text { that do not disclose the fees } \\
\text { paid to the predecessor } \\
\text { auditor. Dep. var. = sum of } \\
\text { predecessor and successor } \\
\text { fees (LAF4) } \\
(1)\end{array}$ & $\begin{array}{l}\text { Sample excludes } \\
\text { auditor change } \\
\text { observations } \\
\text { Dep. var. = LAF1 } \\
=\text { LAF2 = LAF3 = } \\
\text { LAF4 } \\
\text { (2) }\end{array}$ & $\begin{array}{c}\text { Full sample } \\
\text { Dep. var. }= \\
\text { Successor fee } \\
\quad(L A F 1)\end{array}$ & $\begin{array}{c}\text { Full sample } \\
\text { Dep. var. }= \\
\text { Successor's } \\
\text { corrected fee } \\
\left(L A F 1 \_C o r r\right) \\
(4) \\
\end{array}$ \\
\hline INITIAL & $\begin{array}{c}0.0634 * * * \\
{[4.44]}\end{array}$ & & $\begin{array}{c}0.1435^{*} \\
{[1.72]}\end{array}$ & $\begin{array}{c}0.1411 * * * \\
{[13.66]}\end{array}$ \\
\hline$N E X T$ & & $\begin{array}{l}0.0007 \\
{[0.08]}\end{array}$ & & \\
\hline$I N I T I A L \times L D A Y S$ & & & $\begin{array}{c}-0.0653 * * * \\
{[-3.90]}\end{array}$ & \\
\hline LTA & $\begin{array}{c}0.3407 * * * \\
{[42.24]}\end{array}$ & $\begin{array}{c}0.3388 * * * \\
{[41.19]}\end{array}$ & $\begin{array}{c}0.3443 * * * \\
{[42.28]}\end{array}$ & $\begin{array}{c}0.3443 * * * \\
{[42.30]}\end{array}$ \\
\hline$L I Q$ & $\begin{array}{c}-0.0114 * * * \\
{[-8.04]}\end{array}$ & $\begin{array}{c}-0.0109 * * * \\
{[-7.57]}\end{array}$ & $\begin{array}{c}-0.0119 * * * \\
{[-8.34]}\end{array}$ & $\begin{array}{c}-0.0119 * * * \\
{[-8.34]}\end{array}$ \\
\hline$R O A$ & $\begin{array}{c}-0.0819 * * * \\
{[-6.44]}\end{array}$ & $\begin{array}{c}-0.0765 * * * \\
{[-5.83]}\end{array}$ & $\begin{array}{c}-0.0781 * * * \\
{[-6.24]}\end{array}$ & $\begin{array}{c}-0.0781 * * * \\
{[-6.24]}\end{array}$ \\
\hline$L E V$ & $\begin{array}{c}0.0671 * * * \\
{[5.79]}\end{array}$ & $\begin{array}{c}0.0663 * * * \\
{[5.63]}\end{array}$ & $\begin{array}{c}0.0659 * * * \\
{[5.63]}\end{array}$ & $\begin{array}{c}0.0659 * * * \\
{[5.63]}\end{array}$ \\
\hline RECINV & $\begin{array}{c}0.2777 * * * \\
{[6.56]}\end{array}$ & $\begin{array}{c}0.2818 * * * \\
{[6.51]}\end{array}$ & $\begin{array}{c}0.2910 * * * \\
{[6.57]}\end{array}$ & $\begin{array}{c}0.2910^{* * *} \\
{[6.57]}\end{array}$ \\
\hline FOREIGN & $\begin{array}{c}0.0410 * * * \\
{[4.04]}\end{array}$ & $\begin{array}{c}0.0422 * * * \\
{[4.15]}\end{array}$ & $\begin{array}{c}0.0392 * * * \\
{[3.80]}\end{array}$ & $\begin{array}{c}0.0392 * * * \\
{[3.80]}\end{array}$ \\
\hline EXORD & $\begin{array}{c}0.0649 * * * \\
{[3.17]}\end{array}$ & $\begin{array}{c}0.0655 * * * \\
{[3.16]}\end{array}$ & $\begin{array}{c}0.0623 * * * \\
{[3.02]}\end{array}$ & $\begin{array}{c}0.0623 * * * \\
{[3.02]}\end{array}$ \\
\hline SQSEG & $\begin{array}{c}0.0303 * * * \\
{[3.47]}\end{array}$ & $\begin{array}{c}0.0322 * * * \\
{[3.71]}\end{array}$ & $\begin{array}{c}0.0246 * * * \\
{[2.83]}\end{array}$ & $\begin{array}{c}0.0246^{* * *} \\
{[2.83]}\end{array}$ \\
\hline BIG4 & $\begin{array}{c}0.3141 * * * \\
{[17.07]}\end{array}$ & $\begin{array}{c}0.3458 * * * \\
{[17.13]}\end{array}$ & $\begin{array}{c}0.2676 * * * \\
{[15.75]}\end{array}$ & $\begin{array}{c}0.2676^{* * *} \\
{[15.75]}\end{array}$ \\
\hline$G C$ & $\begin{array}{c}0.0660^{* * * *} \\
{[4.53]}\end{array}$ & $\begin{array}{c}0.0731 * * * \\
{[4.93]}\end{array}$ & $\begin{array}{c}0.0731 * * * \\
{[4.97]}\end{array}$ & $\begin{array}{c}0.0731^{* * *} \\
{[4.97]}\end{array}$ \\
\hline$M W$ & $\begin{array}{c}0.2784 * * * \\
{[20.22]}\end{array}$ & $\begin{array}{c}0.2794 * * * \\
{[19.77]}\end{array}$ & $\begin{array}{c}0.2840 * * * \\
{[20.41]}\end{array}$ & $\begin{array}{c}0.2840 * * * \\
{[20.41]}\end{array}$ \\
\hline$D \_M W$ & $\begin{array}{c}0.2563 * * * \\
{[26.79]}\end{array}$ & $\begin{array}{c}0.2569 * * * \\
{[26.48]}\end{array}$ & $\begin{array}{c}0.2602 * * * \\
{[26.96]}\end{array}$ & $\begin{array}{c}0.2602 * * * \\
{[26.96]}\end{array}$ \\
\hline Constant & $\begin{array}{c}10.7637 * * * \\
{[212.09]}\end{array}$ & $\begin{array}{c}10.7507 * * * \\
{[206.61]}\end{array}$ & $\begin{array}{c}10.7788 * * * \\
{[210.08]}\end{array}$ & $\begin{array}{c}10.7787 * * * \\
{[210.17]}\end{array}$ \\
\hline Year Fixed Effects & Yes & Yes & Yes & Yes \\
\hline Company Fixed Effects & Yes & Yes & Yes & Yes \\
\hline Observations & 45,047 & 43,868 & 46,970 & 46,970 \\
\hline Adjusted $R^{2}$ & $81 \%$ & $81 \%$ & $81 \%$ & $81 \%$ \\
\hline
\end{tabular}

***,**, and * represent $\mathrm{p}<.01, .05$, and .1, respectively; T-stats are in brackets.

Table 6 uses three approaches to correct for the bias in audit fees during the auditor change year. In Column (1), we estimate the audit fee model after dropping auditor change observations where the predecessor's audit fee is not disclosed and the dependent variable (LAF4) captures the sum of the fees paid to the predecessor and successor auditors. In Column (2), we drop all auditor change observations and our variable of interest (NEXT) captures the first full year under the successor auditor - in this column the audit fee variables (LAF1, LAF2, LAF3, and LAF4) are 
identical so it makes no difference between audit fee variable is used. Column (3) reports results for the full sample $(\mathrm{N}=46,970)$ and it corrects for the downward bias in the fee paid to the successor auditor (LAF1) by controlling for the number of days between the beginning of the fiscal year and the appointment date of the successor auditor (INITIAL $x$ LDAYS). Column (4) reports results for the full sample $(\mathrm{N}=46,970)$ using the successor auditor's corrected fee (LAF1_Corr). See the Appendix for variable definitions. 
Table 7

Audit quality and fee discounting.

\begin{tabular}{|c|c|c|c|c|c|c|c|}
\hline & $\begin{array}{c}\text { Restatements } \\
\text { RESTATE }\end{array}$ & $\begin{array}{l}\text { Going-concern } \\
\text { opinions } \\
G C\end{array}$ & $\begin{array}{l}\text { Internal control } \\
\text { opinions } \\
M W\end{array}$ & $\begin{array}{c}\text { Abnormal } \\
\text { total accruals } \\
\text { ATA }\end{array}$ & $\begin{array}{c}\text { Performance- } \\
\text { matched abnormal } \\
\text { total accruals } \\
\text { PMATA }\end{array}$ & $\begin{array}{c}\text { Abnormal } \\
\text { current } \\
\text { accruals } \\
\text { ACA }\end{array}$ & $\begin{array}{c}\text { Performance- } \\
\text { matched abnormal } \\
\text { current accruals } \\
P M A C A\end{array}$ \\
\hline \multirow[t]{2}{*}{ INITIAL } & $-0.3189^{* * *}$ & $0.3146^{* *}$ & $0.9038^{* * *}$ & 0.0005 & -0.0047 & 0.0006 & -0.0033 \\
\hline & {$[-3.54]$} & {$[2.48]$} & {$[6.95]$} & {$[0.08]$} & {$[-0.78]$} & {$[0.12]$} & {$[-0.57]$} \\
\hline \multirow[t]{2}{*}{ DISCOUNT } & $-0.0788 *$ & 0.0374 & $0.1646^{*}$ & 0.0026 & 0.0000 & 0.0018 & -0.0004 \\
\hline & {$[-1.70]$} & {$[0.42]$} & [1.93] & {$[0.87]$} & {$[0.01]$} & {$[0.60]$} & {$[-0.13]$} \\
\hline \multirow[t]{2}{*}{ INITIAL $\times$ DISCOUNT } & 0.0277 & 0.1321 & 0.2803 & $-0.0173 * *$ & -0.0112 & $-0.0181 * *$ & -0.0122 \\
\hline & {$[0.21]$} & {$[0.70]$} & {$[1.30]$} & {$[-2.21]$} & {$[-1.37]$} & {$[-2.32]$} & {$[-1.50]$} \\
\hline \multirow[t]{2}{*}{ LTA } & $0.1219 * * *$ & $-0.9798 * * *$ & $-0.2300 * * *$ & $-0.0566^{* * *}$ & $-0.0637 * * *$ & $-0.0543 * * *$ & $-0.0611 * * *$ \\
\hline & {$[7.02]$} & {$[-24.31]$} & {$[-8.29]$} & {$[-18.03]$} & {$[-19.23]$} & {$[-17.67]$} & {$[-18.77]$} \\
\hline \multirow[t]{2}{*}{$R O A$} & $-0.1739 * * *$ & & & $0.4187 * * *$ & $0.3017 * * *$ & $0.4053 * * *$ & $0.2928 * * *$ \\
\hline & {$[-3.08]$} & & & {$[33.76]$} & [24.08] & [34.53] & {$[24.41]$} \\
\hline \multirow[t]{2}{*}{$L E V$} & $0.1155^{* *}$ & $1.5685^{* * *}$ & & 0.0093 & 0.0004 & 0.0106 & 0.0036 \\
\hline & {$[2.35]$} & {$[13.73]$} & & {$[1.10]$} & {$[0.04]$} & {$[1.28]$} & {$[0.42]$} \\
\hline \multirow[t]{2}{*}{ SQSEG } & 0.0746 & & $0.1240 * *$ & 0.0026 & 0.0035 & 0.0019 & 0.0030 \\
\hline & {$[1.54]$} & & {$[1.97]$} & {$[1.14]$} & [1.45] & [0.89] & {$[1.27]$} \\
\hline \multirow[t]{2}{*}{ LOSS } & $0.2534 * * *$ & $2.3151 * * *$ & $0.8430 * * *$ & $-0.0210^{* * *}$ & $-0.0049 *$ & $-0.0203 * * *$ & $-0.0101 * * *$ \\
\hline & {$[5.10]$} & [22.82] & {$[9.40]$} & {$[-7.66]$} & {$[-1.71]$} & {$[-7.62]$} & {$[-3.65]$} \\
\hline \multirow[t]{2}{*}{ FINANCE } & $0.1256 * * *$ & & & $0.0107 * * *$ & $0.0096 * * *$ & $0.0141 * * *$ & $0.0128 * * *$ \\
\hline & {$[3.54]$} & & & {$[5.96]$} & [4.98] & {$[8.00]$} & {$[6.84]$} \\
\hline \multirow[t]{2}{*}{ BIG4 } & -0.0801 & $-0.3271 * * *$ & $-0.3107 * * *$ & $0.0211 * * *$ & $0.0192 * * *$ & $0.0228 * * *$ & $0.0222 * * *$ \\
\hline & {$[-1.04]$} & {$[-2.85]$} & {$[-2.87]$} & {$[4.08]$} & {$[3.57]$} & {$[4.34]$} & [4.11] \\
\hline \multirow[t]{2}{*}{$L I Q$} & & $-0.1750 * * *$ & & & & & \\
\hline & & {$[-7.45]$} & & & & & \\
\hline \multirow[t]{2}{*}{ REPLAG } & & $0.1826 * * *$ & & & & & \\
\hline & & {$[7.07]$} & & & & & \\
\hline \multirow[t]{2}{*}{ EXTREME_SALES } & & & 0.0810 & & & & \\
\hline & & & {$[1.05]$} & & & & \\
\hline
\end{tabular}


Table 7 (cont.)

Audit quality and fee discounting.

\begin{tabular}{|c|c|c|c|c|c|c|c|}
\hline \multicolumn{3}{|l|}{ RZ_SCORE } & $\begin{array}{c}0.0588 * * * \\
{[3.64]}\end{array}$ & $\begin{array}{c}-0.0065^{* * *} \\
{[-6.04]}\end{array}$ & $\begin{array}{c}-0.0008 \\
{[-0.66]}\end{array}$ & $\begin{array}{c}-0.0056^{* * *} \\
{[-5.29]}\end{array}$ & $\begin{array}{c}-0.0003 \\
{[-0.29]}\end{array}$ \\
\hline \multicolumn{3}{|l|}{ RESTRUCTURE } & $\begin{array}{c}0.1639 * * \\
{[2.01]}\end{array}$ & $\begin{array}{c}0.0106^{* * *} \\
{[5.61]}\end{array}$ & $\begin{array}{c}0.0115^{* * *} \\
\quad[5.66]\end{array}$ & $\begin{array}{c}0.0120 * * * \\
{[6.36]}\end{array}$ & $\begin{array}{c}0.0124 * * * \\
{[6.24]}\end{array}$ \\
\hline \multicolumn{3}{|l|}{ GROWTH } & & $\begin{array}{c}-0.0071 * * * \\
{[-2.70]}\end{array}$ & $\begin{array}{c}-0.0069 * * \\
{[-2.54]}\end{array}$ & $\begin{array}{c}-0.0083 * * * \\
{[-3.24]}\end{array}$ & $\begin{array}{c}-0.0083 * * * \\
{[-3.18]}\end{array}$ \\
\hline FOREIGN & & & & $\begin{array}{l}0.0051 \\
{[1.45]}\end{array}$ & $\begin{array}{c}0.0062 * \\
{[1.70]}\end{array}$ & $\begin{array}{l}0.0038 \\
{[1.12]}\end{array}$ & $\begin{array}{l}0.0052 \\
{[1.45]}\end{array}$ \\
\hline EXORD & & & & $\begin{array}{c}0.0048 \\
{[0.94]}\end{array}$ & $\begin{array}{l}0.0059 \\
{[1.05]}\end{array}$ & $\begin{array}{l}0.0039 \\
{[0.72]}\end{array}$ & $\begin{array}{l}0.0055 \\
{[0.94]}\end{array}$ \\
\hline Constant & & & & $\begin{array}{c}0.3420 * * * \\
{[18.84]}\end{array}$ & $\begin{array}{c}0.3465 * * * \\
{[18.16]}\end{array}$ & $\begin{array}{c}0.3219 * * * \\
{[18.17]}\end{array}$ & $\begin{array}{c}0.3296 * * * \\
{[17.58]}\end{array}$ \\
\hline Observations & 46,970 & 46,916 & 28,495 & 44,934 & 44,482 & 45,226 & 44,790 \\
\hline Company Random Effects & Yes & Yes & Yes & No & No & No & No \\
\hline Company Fixed Effects & No & No & No & Yes & Yes & Yes & Yes \\
\hline Year Fixed Effects & Yes & Yes & Yes & Yes & Yes & Yes & Yes \\
\hline Pseudo $\mathrm{R}^{2}$ / Adjusted $\mathrm{R}^{2}$ & $10 \%$ & $16 \%$ & $6 \%$ & $34 \%$ & $18 \%$ & $33 \%$ & $18 \%$ \\
\hline
\end{tabular}

$* * *, * *$ and $*$ represent $\mathrm{p}<.01, .05$, and .1, respectively; $\mathrm{z}$-statistics and t-statistics are in brackets.

Table 7 presents several tests of the link between initial year fee discounting and audit quality. Columns (1) - (3) employ random-effects logistic regressions that use three proxies for audit quality: accounting restatements (RESTATE), going-concern audit reports (GC), and adverse internal control reports (MW). The sample used in Column (3) includes only the auditor change observations that have SOX 404(b) audit opinions on internal controls. Columns (4) - (7) estimate abnormal accruals models, using abnormal total accruals (ATA), performance-matched abnormal total accruals (PMATA), abnormal current accruals (ACA), and performancematched abnormal current accruals (PMACA). The variable of interest in all seven columns is INITIAL $\times$ DISCOUNT, where INITIAL is an indicator variable for initial-year audit engagements and DISCOUNT is an indicator variable that equals one if the successor's corrected audit fee (LAF Corr) is less than the predicted audit fee based on the regression reported in Column (4) of Table 6. 